\title{
ZAŠTITA OVRŠENIKA U SVJETLU NOVINA U OVRSI NA NEKRETNINI**
}

Sažetak: Cilj je rada raspraviti $i$ analizirati novine koje su posljednjim izmjenama $i$ dopunama Ovršnog zakona unesene u postupak ovrhe na nekretnini u odnosu na zaštitu ovršenika te nekretnine u kojoj stanuje i koja je nužna za zadovoljenje njegovih osnovnih životnih potreba i osoba koje je po zakonu dužan uzdržavati.

U tom kontekstu, u radu je sadržana sumarna povijesna geneza uređenja ovrhe na nekretnini, posebice u odnosu na zaštitu ovršenika od donošenja prvog Ovršnog zakona iz 1996. pa do Zakona iz 2012. godine. Potom slijedi analiza i rasprava o novinama Zakona o izmjenama i dopunama Ovršnog zakona iz 2014. u odnosu na zaštitu ovršenika, odnosno nekretnine u kojoj stanuje i koja je nužna za zadovoljenje njegovih osnovnih stambenih potreba i osoba koje je po zakonu dužan uzdržavati. U trećem dijelu rada sadržana je analiza novije odluke Europskog suda za ljudska prava (u daljnjem tekstu: Sud) u predmetu Vaskrsić protiv Slovenije, a u kojem je Sud - različito od dosadašnje prakse - odlučivao o povredi prava na mirno uživanje vlasništva iz čl. 1. Protokola 1. uz Konvenciju za zaštitu ljudskih prava i temeljnih sloboda u ovršnom postupku. Pritom je Sud istaknuo potrebu primjene testa razmjernosti i u postupku ovrhe na nekretnini. Raspravu o predmetu Vaskrsić protiv Slovenije slijedi analiza i rasprava o novinama koje je u postupak ovrhe na nekretnini u odnosu na zaštitu ovršenika unio posljednji Zakon o izmjenama i dopunama Ovršnog zakona iz srpnja 2017. godine. Konačno, u zaključnom dijelu rada sadržan je sažetak provedenog istraživanja, evaluacija novina koje su unesene u postupak ovrhe na nekretnini u odnosu na zaštitu ovršenika te nekretnine koja je nužna za zadovoljenje njegovih osnovnih životnih potreba, kao i promišljanja autora o novom pravozaštitnom cilju ovršnog postupka.

Ključne riječi: $\quad$ ovrha na nekretnini, zaštita ovršenika, Europski sud za ljudska prava, Zakon o izmjenama i dopunama Ovršnog zakona iz 2017., postupak

\footnotetext{
* Dr. sc. Slađana Aras Kramar, docentica na Katedri za građansko procesno pravo Pravnoga fakulteta Sveučilišta u Zagrebu. Trg Republike Hrvatske 14, 10000 Zagreb, Republika Hrvatska. Adresa e-pošte: saras@pravo.hr. ORCID: http://orcid.org/00000002-8908-775X.

** Ovaj rad je nastao u okviru projekta "Novi hrvatski pravni sustav", Pravnoga fakulteta Sveučilišta u Zagrebu (2017.), znanstvena tema "Novine u ovrsi na nekretnini".
} 


\section{UVOD}

Radi povećanja učinkovitosti postupka ovrhe na nekretnini, ponajprije ubrzanja postupka prodaje nekretnina u ovršnom postupku te, s druge strane, zaštite ovršenika, točnije nekretnine u kojoj stanuje i koja je nužna za zadovoljenje njegovih osnovnih stambenih potreba i osoba koje je po zakonu dužan uzdržavati, 2014. godine donesen je Zakon o izmjenama i dopunama Ovršnog zakona. ${ }^{1},{ }^{2}$ Tim se Zakonom prvi put ozbiljnije interveniralo u ovršnopravni sustav uspostavljen stupanjem na snagu Ovršnog zakona iz 2012., ${ }^{3}$ ali i u odredbe o ovrsi na nekretnini. Uz uvođenje elektroničkih javnih dražbi koje provodi Financijska agencija, ${ }^{4}$ ZIDOZ-om $14 \mathrm{u}$ OZ 12 bile su unesene odredbe koje su imale za cilj (privremeno) zaštititi nekretninu u kojoj ovršenik stanuje i koja je nužna za zadovoljenje njegovih osnovnih stambenih potreba i osoba koje je po zakonu dužan uzdržavati. ${ }^{5}$

Prihvaćanjem izmjena i dopuna OZ-a 12 2014. godine u Hrvatskoj je započeo proces promišljanja (na različitim razinama, kao i različitih dionika) treba li i kako (trajno) zaštiti od ovrhe, drugim riječima izuzeti od ovrhe jedinu nekretninu ovršenika u kojoj on stanuje i koja je nužna za zadovoljenje njegovih osnovnih životnih potreba i osoba koje je po zakonu dužan uzdržavati. ${ }^{6}$ To je, među ostalim, bilo potaknuto i praksom Europskog suda za ljudska prava (u daljnjem tekstu i: Europski sud, Sud) ${ }^{7}$ te Ustavnog sud Republike Hrvatske ${ }^{8}$ koja se, doduše, u prvom redu odnosila na zaštitu prava na dom ${ }^{9}$

1 Zakon o izmjenama i dopunama Ovršnog zakona iz 2014. godine, Narodne novine Republike Hrvatske, broj 93/2014 (u daljnjem tekstu: ZIDOZ 14).

2 Vidjeti Konačni prijedlog Zakona o izmjenama i dopunama Ovršnog zakona iz 2014. godine, Zagreb, lipanj 2014., URL=http://www. sabor.hr/konacni-prijedlog-zakona-o-izmjenama-i-dopunama-ov, str. 26.-27. Pristupljeno 13. srpnja 2017.

3 Ovršni zakon iz 2012. godine, Narodne novine Republike Hrvatske, broj 112/2012, s kasnijim izmjenama i dopunama: Narodne novine Republike Hrvatske, broj 25/2013 - v. čl. 101. Zakona o izmjenama i dopunama Zakona o parničnom postupku iz 2013. 93/2014, 55/2016 - v. Odluku Ustavnog suda Republike Hrvatske, broj: U-I-2881/2014 i dr. od 1. 6. 2016., 73/2017. (u daljnjem tekstu: OZ 12; Zakon iz 2012.).

4 Vidjeti čl. 95.a, čl. 97. te čl. 132.a - čl. 132.i OZ-a 12.

$5 \quad$ Vidjeti prij. čl. 84.a, prij. čl. 127. st. 2. - 5. OZ-a 12.

6 Vidjeti Barbić, J. (ur.), Pravo na dom, Hrvatska akademija znanosti i umjetnosti, Zagreb, 2016. Publikacija je rezultat Okruglog stola održanog 28. siječnja 2016. u palači Akademije u Zagrebu. Vidjeti i Kontrec, D., Pravo na dom u praksi Europskog suda $i$ domaćih sudova, Aktualnosti hrvatskog zakonodavstva i pravne prakse: građansko, trgovačko, radno i procesno pravo u praksi, Godišnjak 23, 2016., str. 29.-65., posebno str. 58.-61.; Bugarin, B., Ovrha i pravo na dom, Hrvatska pravna revija, god. 16, br. 6, 2016., str. 14.-20.; Mihelčić, G.; Marochini, M., Reforma ovrhe na nekretnini u hrvatskom pravu u svjetlu konvencijskog prava, Zbornik radova Aktualnosti građanskog i trgovačkog zakonodavstva i pravne prakse, br. 12, Mostar, 2014., str. 200.-213. Za nacrte prijedloga Zakona o izmjenama i dopunama Ovršnog zakona iz 2016. i 2017. v. infra ad bilj. 14.-16.

7 Za sustavni prikaz odluka Europskog suda za ljudska prava u odnosu na pravo na dom, a u kojima je stranka bila Republika Hrvatska v. Maganić, A., Praksa Europskog suda za ljudska prava i pravo na dom, u: Barbić, J. (ur.), Pravo na dom, Hrvatska akademija znanosti i umjetnosti, Zagreb, 2016., str. 30.-53.

8 Za prikaz odluka Ustavnog suda Republike Hrvatske u odnosu na pravo na dom v. Marković, S., Stajališta Ustavnog suda Republike Hrvatske o ustavnim i konvencijskim jamstvima zaštite prava na dom u smislu članka 34. Ustava, u: Barbić, J. (ur.), Pravo na dom, Hrvatska akademija znanosti i umjetnosti, Zagreb, 2016., str. 60.-81.

9 Čl. 8. Konvencije za zaštitu ljudskih prava i temeljnih sloboda (Narodne novine Republike Hrvatske, Međunarodni ugovori, broj 18/1997, 6/1999, 8/1999, 14/2002, 13/2003, 9/2005, 1/2006, 2/2010; u daljnjem tekstu: EK) glasi: "1. Svatko ima pravo na poštovanje svoga privatnog i obiteljskog života, doma i dopisivanja.

2. Javna vlast se neće miješati u ostvarivanje tog prava, osim u skladu sa zakonom i ako je u demokratskom društvu nužno radi interesa državne sigurnosti, javnog reda i mira, ili gospodarske dobrobiti zemlje, te radi sprečavanja nereda ili zločina, radi zaštite zdravlja ili morala ili radi zaštite prava i sloboda drugih." 
u parničnom postupku. ${ }^{10}$ Ipak u novije vrijeme svjedočimo i odluci Suda u predmetu u kojem je povrijeđeno pravo na mirno uživanje vlasništva iz čl. 1. Protokola br. 1. uz EK ${ }^{11}$ prodajom nekretnine u postupku ovrhe. ${ }^{12}$

Nastojanja da se izuzme od ovrhe jedina nekretnina ovršenika u kojoj on stanuje i koja je nužna za zadovoljenje njegovih osnovnih životnih potreba i osoba koje je po zakonu dužan uzdržavati, skraćeno nazvana "dom", ${ }^{13}$ rezultirala su, prvo, Nacrtom prijedloga Zakona o izmjenama i dopunama Ovršnog zakona iz svibnja 2016. godine. ${ }^{14}$ Potom, nakon prijevremenih izbora u rujnu 2016. godine, objavljen je Prijedlog Zakona o izmjenama i dopunama Ovršnog zakona iz listopada 2016., ${ }^{15}$ da bi u travnju 2017. bio upućen u drugo čitanje Hrvatskom saboru Konačni prijedlog Zakona o izmjenama i dopunama Ovršnog zakona. ${ }^{16}$ Navedenim se prijedlozima, doduše na različiti način, pokušalo poboljšati položaj ovršenika u slučaju ovrhe na nekretnini, pa i izuzimanjem od ovrhe nekretnine pod određenim pretpostavkama. Opisani je proces rezultirao Zakonom o izmjenama i dopunama Ovršnog zakona koji je donesen 14. srpnja 2017. godine. ${ }^{17}$ Taj je Zakon donesen s velikim (političkim) konsenzusom. ${ }^{18}$ Njime

10 Zaštita prava na dom te primjena testa razmjernosti počela se problematizirati u Hrvatskoj, posebice od strane sudova, (tek) nakon što je Europski sud za ljudska prava utvrdio povredu tog prava sadržanog u čl. 8. EK-a u pojedinim predmetima. U pravilu riječ je bila o parničnim postupcima radi ostvarenja zahtjeva za povrat nekretnine gdje se pravo na dom suprotstavljalo drugom konvencijskom pravu: pravu vlasništva, i to u pravilu osoba javnoga prava. Zaštita prava na dom iz čl. 8. EK-a, naime, ima u Hrvatskoj svoje specifičnosti koje su posljedica nekadašnjeg stanarskog prava koje je postojalo na stanovima u društvenom vlasništvu. Kontrec, D., op. cit. u bilj. 6, str. 44., 53.-58., 61.-64.; Maganić, A., op. cit. u bilj. 7, str. 30. et seq.

11 Čl. 1. Protokola br. 1. uz EK glasi: "Svaka fizička ili pravna osoba ima pravo na mirno uživanje svojega vlasništva. Nitko se ne smije lišiti svoga vlasništva, osim u javnom interesu, i to samo uz uvjete predviđene zakonom i općim načelima međunarodnog prava. Prethodne odredbe, međutim, ni na koji način ne umanjuju pravo države da primijeni zakone koje smatra potrebnima da bi uredila upotrebu vlasništva u skladu s općim interesom ili za osiguranje plaćanja poreza ili drugih doprinosa ili kazni."

12 Vidjeti Europski sud za ljudska prava: predmet Vaskrsić protiv Slovenije, presuda od 25. travnja 2017. Dostupno na: URL=http:// hudoc.echr.coe.int/eng\#\{“languageisocode”:[“ENG”],"respondent”:[“SVN"]," documentcollectionid2”:[“JUDGMENTS”],"itemid”: [“001-173102"]\}. Pristupljeno: 13. srpnja 2017. Za analizu Presude v. infra ad 3.

13 Treba primijetiti da se koncept "dom" razvijen u praksi Europskog suda za ljudska prava razlikuje od određenja OZ-a 12: "Nekretnina u kojoj ovršenik stanuje i koja je nužna za zadovoljenje osnovnih životnih/stambenih potreba ovršenika i osoba koje je po zakonu dužan uzdržavati” (v. nov. čl. 75. st. 5. OZ-a 12; prij. čl. 84.a st. 1. i st. 4. t. 1., prij. čl. 127. st. 2. OZ-a 12). U određenju autonomnog koncepta "dom" u praksi Europskog suda ističu se sljedeći elementi: činjenična narav te neposredna i trajna veza osobe s prostorom. O tome v. Mihelčić, G.; Marochini, M., op. cit. u bilj. 6, str. 204.-205.; Kontrec, D., op. cit. u bilj. 6, str. 31.-34. U radu će se stoga koristiti terminologija iz OZ-a 12.

14 Nacrt prijedloga Zakona o izmjenama i dopunama Ovršnog zakona iz svibnja 2016. godine, Zagreb, svibanj 2016. Dostupno na: URL= https://esavjetovanja.gov.hr/ECon/MainScreen?entityId=3365. Pristupljeno: 13. srpnja 2017.

15 Prijedlog Zakona o izmjenama i dopunama Ovršnog zakona iz listopada 2016. godine, Zagreb, listopad 2016. Dostupno na:URL= www.sabor.hr/fgs.axd?id=46799. Pristupljeno: 13. srpnja 2017. (u daljnjem tekstu i: P ZIDOZ iz listopada 2016.) Za Izvješće Odbora za pravosuđe Hrvatskog sabora od 18. listopada 2016. o Prijedlogu Zakona o izmjenama i dopunama Ovršnog zakona iz listopada 2016. v. URL= http://www.sabor.hr/izvjesce-odbora-za-pravosude-o-prijedlogu-zako0034. Pristupljeno: 13. srpnja 2017.

16 Konačni prijedlog Zakona o izmjenama i dopunama Ovršnog zakona iz travnja 2017. godine, Zagreb, travanj 2017. Dostupno na: URL=http://www.sabor.hr/konacni-prijedlog-zakona-o-izmjenama-i-dopunam0035. Pristupljeno: 13. srpnja 2017. (u daljnjem tekstu i: KP ZIDOZ iz travnja 2017.).

17 Zakon o izmjenama i dopunama Ovršnog zakona iz 2017. godine, Narodne novine Republike Hrvatske, broj 73/2017 (u daljnjem tekstu: ZIDOZ 17). Pretežni dio odredaba ZIDOZ-a 17 stupio je na snagu osmoga dana od dana objave u Narodnim novinama (dakle, 3. kolovoza 2017. godine). To se odnosi i na odredbe ZIDOZ-a 17 kojim su unesene novine u odredbe OZ-a 12 o zaštiti ovršenika u ovrsi na nekretnini (čl. 47. ZIDOZ-a 17).

18 ZIDOZ 17 donesen je jednoglasno (127 glasova “za"). Vidjeti URL=http://www.sabor.hr/konacni-prijedlog-zakona-o-izmjenamai-dopunam0035. Pristupljeno 17. srpnja 2017. 
se, čini se, posljedično mijenja kako koncept tako i pravozaštitni cilj koji se konvencionalno pripisivao ovršnom postupku. ${ }^{19}$

Cilj rada je raspraviti i analizirati novine koje su posljednjim izmjenama i dopunama OZ-a 12 unesene u postupak ovrhe na nekretnini u odnosu na zaštitu ovršenika te nekretnine u kojoj stanuje i koja je nužna za zadovoljenje njegovih osnovnih životnih potreba i osoba koje je po zakonu dužan uzdržavati. U tom kontekstu, u radu je sadržana sumarna povijesna geneza uređenja ovrhe na nekretnini, posebice u odnosu na zaštitu ovršenika od donošenja prvog Ovršnog zakona iz $1996 .{ }^{20}$ pa do OZ-a 12. Potom slijedi analiza i rasprava o novinama koje je ZIDOZ 14 unio u uređenje ovrhe na nekretnini u odnosu na zaštitu ovršenika, odnosno nekretnine u kojoj stanuje i koja je nužna za zadovoljenje njegovih osnovnih stambenih potreba i osoba koje je po zakonu dužan uzdržavati.

U trećem dijelu rada sadržana je analiza novije odluke Europskog suda za ljudska prava u predmetu Vaskrsić protiv Slovenije, a u kojem je Sud - različito od dosadašnje prakse - odlučivao o povredi prava na mirno uživanje vlasništva, sadržanog u čl. 1. Protokola 1. uz EK, ovršnom prodajom nekretnine podnositelja zahtjeva. Pritom je Sud istaknuo, što je važno u kontekstu teme ovoga rada, potrebu primjene testa razmjernosti i u postupku ovrhe na nekretnini. Raspravu o predmetu Vaskrsić protiv Slovenije slijedi analiza i rasprava o novinama koje su u postupak ovrhe na nekretnini u odnosu na zaštitu ovršenika unesene zadnjim izmjenama i dopunama Ovršnog zakona iz srpnja 2017. godine (ZIDOZ 17). Konačno, u zaključnom dijelu rada sadržan je sažetak provedenog istraživanja, evaluacija novina koje su unesene u postupak ovrhe na nekretnini u odnosu na zaštitu ovršenika te nekretnine koja je nužna za zadovoljenje njegovih osnovnih životnih potreba i osoba koje je po zakonu dužan uzdržavati, kao i promišljanja autora o novom pravozaštitnom cilju ovršnog postupka.

\section{SUMARNA POVIJESNA GENEZA UREĐENJA OVRHE NA NEKRETNINI TE ZAŠTITE OVRŠENIKA: OD OZ-A 96 DO OZ-A 12}

\subsection{OZ 96}

OZ 96 je bio prvi Ovršni zakon koji je donesen nakon osamostaljenja te stjecanja neovisnosti Republike Hrvatske. Njime je ovrha na nekretnini bila uređena kao sudska ovrha, sud ju je

19 Prema Dika, M., Građansko ovršno pravo, I. knjiga, Opće građansko ovršno pravo, Narodne novine, Zagreb, 2007., str. 8.: "Ovršni postupak je niz pravno uređenih i funkcionalno koordiniranih radnji suda, stranaka i drugih subjekata toga postupka koje imaju za cilj prisilno ostvarenje ovrhovoditeljeve tražbine." (podcrtao autor). Prema ibid., str. 37.: "Pravozaštitni je cilj ovršnog postupka prisilno ostvariti tražbinu ovrhovoditelja, utvrđenu u ispravi koja ima značenje osnove za ovrhu, iz pojedinačno određenih dijelova (u odnosu na pojedinačno određene dijelove) imovine ovršenika, odnosno navođenjem ovršenika na individualno određeno ponašanje (individualna egzekucija)." (Istaknuo autor.) novine Republike Hrvatske, broj 29/1999, 42/2000 - v. Odluku i Rješenje Ustavnog suda Republike Hrvatske, broj: U-I-510/1996, U-I-717/1996, U-I-1025/1999 od 5. travnja 2000., 173/2003, 194/2003 - v. Ispravak Zakona o izmjenama i dopunama Ovršnog zakona iz 2003., 151/2004, 88/2005, 121/2005 - v. Zakon o Upisniku sudskih i javnobilježničkih osiguranja tražbina vjerovnika na pokretnim stvarima i pravima, 67/2008, 139/2010 - v. čl. 339. Ovršnog zakona iz 2010. (u daljnjem tekstu: OZ 96; Zakon iz 1996.). 
određivao te provodio. ${ }^{21}$ Ovrha na nekretnini provodila se, kao i danas (čl. 80. OZ-a 12), zabilježbom ovrhe u zemljišnoj knjizi, utvrđenjem vrijednosti nekretnine, prodajom nekretnine i namirenjem ovrhovoditelja iz iznosa dobivenoga prodajom (čl. 75. OZ-a 96).

Među svojim osnovnim odredbama, OZ 96 propisivao je zaštitu dostojanstva ovršenika. Pri provedbi ovrhe pazilo se na dostojanstvo ovršenika te na to da ovrha za njega bude što manje nepovoljna (čl. 6. OZ-a 96). Međutim, promatrajući odredbe o zaštiti nekretnina za stanovanje ovršenika, OZ 96 određivao je da se nekretnine za stanovanje (ili obavljanje poslovne djelatnosti) nisu smatrale stvarima koje su bile nužne za zadovoljavanje osnovnih životnih potreba ovršenika i osoba koje je po zakonu bio dužan uzdržavati (ili za obavljanje samostalne djelatnosti koja je bila njegov glavni izvor sredstava za život) i kao takve izuzete od ovrhe, osim ako zakonom nije bilo drukčije određeno (čl. 70. st. 5. OZ-a 96).

OZ 96 nije sadržavao pravila o redoslijedu prema kojemu su pojedini dijelovi imovine ovršenika mogli biti predmetom ovrhe u smislu da se prvo trebalo pokušati s ovrhom na novčanim tražbinama ovršenika pa tek (kao posljednja) s ovrhom na nekretnini. ${ }^{22}$ Međutim, prema izvornom uređenju OZ-a 96, ovršenik je mogao u roku od osam dana od dana dostave rješenja o ovrsi predložiti da se ovrha odredi na drugom predmetu ovrhe. ${ }^{23} \mathrm{Uz}$ prijedlog, ovršenik je bio dužan podnijeti dokaz o svom pravu na drugom predmetu ovrhe na temelju kojega je na tom predmetu bilo moguće odrediti ovrhu protiv ovršenika (prij. čl. 78. st. 1. OZ-a 96). Sud je taj prijedlog ovršenika dostavljao ovrhovoditelju koji se o njemu mogao očitovati u roku od osam dana od dana dostave. ${ }^{24} \mathrm{U}$ tom je roku ovrhovoditelj mogao i postaviti zahtjev za naknadu troškova započetoga postupka ovrhe na nekretnini te zatražiti davanje osiguranja za naknadu štete koju je mogao trpjeti zbog promjene predmeta ovrhe (prij. čl. 78. st. 2. OZ-a 96). ${ }^{25}$

Sud je mogao prihvatiti prijedlog za promjenu predmeta ovrhe ako je ovršenik učinio vjerojatnim (1) da je ovrha na nekretnini na kojoj je ona bila predložena za njega bila osobito nepovoljna, (2) da zbog opravdanih razloga nije sam mogao unovčiti predmet koji je bio predložio kao novi predmet ovrhe i dobivenim sredstvima namiriti ovrhovoditelja, te (3) da se tražbina ovrhovoditelja mogla u cijelosti namiriti iz drugoga predloženoga predmeta ovrhe (prij. čl. 78. st. 4. OZ-a 96). Ako je ovršenik kao drugo sredstvo ovrhe bio predložio ovrhu na plaći, mirovini, invalidnini ili drugom stalnom novčanom primanju, sud je mogao prihvatiti prijedlog uz uvjet da je ovršenik učinio vjerojatnim da će tražbina biti namirena u roku od jedne godine od

21 Vidjeti čl. 74., čl. 87., čl. 90., čl. 92. OZ-a 96.

22 Tako je, primjerice, prema izvornom uređenju Zakona o izvršnom postupku iz 1978. godine (Službeni list Socijalističke Federativne Republike Jugoslavije, broj 20/1978; u daljnjem tekstu: ZIP) bilo propisano u vezi s imovinom pravnih osobaovršenika (v. čl. 192. ZIP-a). Vidjeti i Dika, M., Ovrha na nekretnini, u: Barbarić, K., Nekretnine u pravnom prometu - pravni i porezni aspekti, Inženjerski biro, Zagreb, prosinac 1998., str. 132.

23 “Time se (...) htjelo, uvažavajući značenje nekretnine kao elementa imovine ovršenika i njene potencijalne važnosti za njegovu egzistenciju odnosno obavljanje djelatnosti, omogućiti ovršeniku da ishodi zamjenu toga objekata ovrhe nekim drugim (...)." Tako ibid., str. 140.

24 Ako je ovrhovoditelj na nekretnini na kojoj je zatražio ovrhu prije pokretanja ovršnoga postupka stekao založno pravo radi osiguranja svoje tražbine, bez njegova se pristanka ovrha nije mogla odrediti na drugom predmetu ovrhe (prij. čl. 78. st. 6. OZ-a 96).

25 Ako je ovrhovoditelj to zatražio, sud je prihvaćanje prijedloga ovršenika uvjetovao davanjem osiguranja da će troškovi ovrhovoditelja u pokrenutom postupku ovrhe na nekretnini koji su bili nastali do donošenja rješenja o promjeni predmeta ovrhe biti u cijelosti namireni odmah po donošenju toga rješenja, te davanjem osiguranja za naknadu štete koju je ovrhovoditelj mogao pretrpjeti zbog promjene predmeta ovrhe. Pritom ako ovršenik nije dao osiguranje u roku koji je sud bio odredio, smatralo se da je odustao od prijedloga za promjenu predmeta ovrhe (prij. čl. 78. st. 8. OZ-a 96). 
donošenja rješenja o njegovu prijedlogu (prij. čl. 78. st. 7. OZ-a 96). Sud nije prihvaćao prijedlog za promjenu predmeta ovrhe ako bi bio ocijenio da bi se zbog toga ovrha znatnije oduljila ili otežala, odnosno ako je ovrhovoditelj zbog toga mogao trpjeti znatniju štetu (prij. čl. 78. st. 5. OZ-a 96). Ako je bio određen drugi predmet ovrhe, zabilježba ovrhe na nekretnini ostajala je na snazi sve do namirenja tražbine ovrhovoditelja (prij. čl. 78. st. 11. OZ-a 96). Citirane su odredbe izvornog uređenja Zakona iz 1996. o promjeni predmeta ovrhe na prijedlog ovršenika u ovrsi na nekretnini, međutim, bile brisane Zakonom o izmjenama i dopunama Ovršnog zakona iz 2003. godine. ${ }^{26},{ }^{27}$

Zakon iz 1996. nije sadržavao odredbu prema kojoj bi ovrha bila nedopuštena ako bi tražbina koja se imala ostvariti bila nerazmjerno manja od vrijednosti nekretnine. Unatoč tomu, javila se praksa u tom smjeru. Sudovi, naime, pozivom na odredbu čl. 6. o zaštiti dostojanstva ovršenika nisu dopuštali prodaju nekretnine na javnoj dražbi kada je postojao očiti nerazmjer između visine tražbine ovrhovoditelja te vrijednosti nekretnine ovršenika. ${ }^{28}$

Promatrajući odredbe OZ-a 96 o odgodi ovrhe na prijedlog ovršenika, okolnost da je ovrha bila predložena na nekretnini ovršenika u kojoj je on stanovao te koja je bila nužna za zadovoljenje njegovih osnovnih stambenih potreba i osoba koje je po zakonu bio dužan uzdržavati nije sama po sebi predstavljala razlog za odgodu ovrhe, ${ }^{29}$ niti je u slučaju prodaje bilo kakvih specifičnosti glede iseljenja ovršenika iz takvih nekretnina. ${ }^{30}$ Pritom je prema izvornom uređenju OZ-a 96 bilo propisano pravo ovršenika i članova njegova obiteljskoga domaćinstva koji su se iseljavali na nužni smještaj samo ako je to bilo određeno posebnim propisom. ${ }^{31}$ Osiguranje nužnoga smještaja nije sprječavalo provedbu ovrhe (prij. čl. 122. OZ-a 96). Stoga se ona mogla provesti neovisno o tome je li ili nije bio osiguran nužni smještaj koji se (eventualno) trebao osigurati. ${ }^{32}$ Navedena je odredba prij. čl. 122. OZ-a 96, međutim, bila brisana ZIDOZ-om 03.

Prodaja nekretnine obavljala se usmenom javnom dražbom (čl. 92. st. 1. OZ-a 96), a njoj je prethodila ovršna radnja utvrđivanja vrijednosti nekretnine (čl. 87. OZ-a 96). ${ }^{33}$ Upravo je za razmatranje položaja ovršenika prema OZ-u 96, važno analizirati i odredbe o načinu utvrđivanja vrijednosti nekretnine te prodajnoj cijeni, a te su odredbe ujedno bile i predmet (čestih) izmjena i dopuna Zakona iz 1996.

26 Zakon o izmjenama i dopunama Ovršnog zakona iz 2003. godine, Narodne novine Republike Hrvatske, broj 173/2003 (u daljnjem tekstu: ZIDOZ 03).

27 O promjeni predmeta ovrhe u ovrsi na nekretnini prema izvornom uređenju OZ-a 96. v. više u: Dika, M., Ovrha..., op. cit. u bilj. 22, str. 140.-142.

28 Tako prema Stokić, M., Vrijednosna ograničenja za ovršnu prodaju nekretnina kao sredstvo zaštite ovršenika, Aktualnosti hrvatskog zakonodavstva i pravne prakse: građansko, trgovačko, radno i procesno pravo u praksi, Godišnjak 22, 2015., str. 769.

29 Vidjeti odredbe čl. 61. OZ-a 96 o odgodi ovrhe na prijedlog ovršenika. O mogućnosti promjena predmeta ovrhe na prijedlog ovršenika prema izvornom uređenju OZ-a 96 v. supra u radu.

30 Vidjeti odredbe čl. 120., čl. 121. te čl. 121.a OZ-a 96.

31 Taj propis nije bio donesen. Tako Dika, M., Ovrha..., op. cit. u bilj. 22, str. 166.

32 Usp. loc. cit.

33 Pritom stranke, založni vjerovnici i nositelji osobnih služnosti i stvarnih tereta koje su bile prestajale prodajom nekretnine mogli su se sporazumjeti najkasnije do prodaje nekretnine na javnoj dražbi da se prodaja nekretnine obavi u određenom roku neposrednom pogodbom preko osobe ovlaštene za promet nekretnina, sudskoga ovršitelja, javnoga bilježnika ili na drugi način (čl. 92. t. 4. OZ-a 96). 
Prema izvornom uređenju Zakona iz 1996., vrijednost nekretnine utvrđivala se na temelju procjene vještaka i drugih činjenica u visini njezine tržišne cijene na dan procjene. Pri utvrđivanju vrijednosti nekretnine vodilo se računa i o tome koliko je ona manje vrijedila zbog toga što su na njoj bila ostala određena prava i poslije prodaje (prij. čl. 87. st. 3. OZ-a 96). Pritom je sud umjesto procjene vještaka mogao utvrđivanje vrijednosti nekretnine zatražiti od nadležnoga tijela porezne uprave (prij. čl. 87. st. 4. OZ-a 96). O načinu utvrđivanja vrijednosti nekretnine sud je bio dužan odlučiti zaključkom odmah nakon što donese rješenje o ovrsi, a ako je to bilo potrebno, sud je prije donošenja zaključka mogao održati ročište sa strankama (prij. čl. 87. st. 1. OZ-a 96).

Zakonom o izmjenama i dopunama Ovršnog zakona iz 2005. godine ${ }^{34}$ odustalo se od vještačenja kao (u načelu) obvezatne metode utvrđivanja vrijednosti nekretnine, a sve radi ubrzanja te pojeftinjenja postupka. ${ }^{35}$ Tako, nakon ZIDOZ-a 05, vrijednost nekretnine sud je utvrđivao zaključkom po slobodnoj ocjeni nakon održanog ročišta na kojemu je strankama bilo omogućeno da se o tome izjasne te da prilože odgovarajuće pisane dokaze. Podatke o stanju na tržištu nekretnina sud je mogao (i dalje) zatražiti i od porezne uprave, ako je ocijenio da je to bilo potrebno (čl. 87. st. 1. OZ-a 96). ${ }^{36}$ Također, pri utvrđivanju vrijednosti nekretnine sud je bio dužan voditi računa i o tome koliko je ona manje vrijedila zato što su na njoj ostala određena prava i tereti i nakon prodaje (čl. 87. st. 2. OZ-a 96).

I nakon ZIDOZ-a 05 vrijedilo je pravilo prema kojemu, ako su u sudskom ili izvansudskom sporazumu na temelju kojega je bilo stečeno založno pravo na nekretnini radi osiguranja tražbine čije se namirenje tražilo stranke utvrdile vrijednost nekretnine, vrijednost nekretnine (u načelu) nije se posebno utvrđivala, nego se kao njezina vrijednost uzimala u sporazumu utvrđena vrijednost (prij. čl. 87. st. 6. OZ-a 96; čl. 87. st. 3. OZ-a 96). ${ }^{37}$

Na prvom ročištu za dražbu, prema izvornom uređenju Zakona iz 1996., nekretnina se nije mogla prodati ispod četiri petine utvrđene vrijednosti (prij. čl. 97. st. 1. OZ-a 96). Ako se nekretnina nije prodala na prvom ročištu, sud je zakazivao drugo ročište na kojemu se nekretnina mogla prodati ispod četiri petine utvrđene vrijednosti, ali ne ispod polovine te vrijednosti (prij. čl. 97. st. 2. OZ-a 96). Stranke i osobe koje su se namirivale u postupku, međutim, mogle su se sporazumjeti, izjavom danom na zapisnik kod suda pred kojim je ovršni postupak bio u tijeku ili drugoga suda, da se nekretnina može prodati dražbom i za cijenu nižu od navedenih (prij. čl. 97. st. 4. OZ-a 96). Također, ako su se stranke prije nego što je bio pokrenut ovršni postupak u sporazumu sklopljenom pred sudom ili u obliku javnobilježničke isprave bile suglasile da se nekretnina radi naplate tražbine ovrhovoditelja koja je bila utvrđena tim sporazumom

34 Zakon o izmjenama i dopunama Ovršnog zakona iz 2005. godine, Narodne novine Republike Hrvatske, broj 88/2005 (u daljnjem tekstu: ZIDOZ 05).

35 Dika, M., Građansko..., op. cit. u bilj. 19, str. 461. Utvrđivanje vrijednosti nekretnine prema izvornom uređenju Zakona iz 1996. u praksi je često trajalo neprimjereno dugo (dulje od godinu dana). Osim toga, mogućnost izbora metoda utvrđivanja vrijednosti nekretnine otvaralo je vrata manipulacijama s utvrđenom vrijednošću, posebice od strane ovršenika. Tako Hrastinski Jurčec, Lj., Ovrha na nekretninama, Javni bilježnik, god. 10, 2006., br. 23, str. 19. Tomu treba pridodati i povećane troškove do kojih je dolazilo u slučaju primjene te metode utvrđivanja vrijednosti nekretnine. Tako Čuveljak, J., O ovrsi na nekretnini, Hrvatska pravna revija, br. 7-8, 2007., str. 108. Vidjeti i Konačni prijedlog Zakona o izmjenama i dopunama Ovršnog zakona iz 2005. godine, Zagreb, svibanj 2005., URL=www.sabor.hr/fgs.axd?id=4617, obrazloženje uz čl. 50. ZIDOZ-a 05. Pristupljeno 14. srpnja 2017. 
može prodati i za cijenu nižu od one koja je bila utvrđena Zakonom iz 1996., nekretnina se već na prvom ročištu za prodaju mogla prodati po toj cijeni ako u postupku nisu sudjelovale druge osobe koje su se u njemu namirivale, a svoje su pravo bile upisale u zemljišnu knjigu prije nego što je u tu knjigu bilo upisano pravo ovrhovoditelja kojim je time bila osigurana naplata njegove tražbine. Najniža cijena prema kojoj se nekretnina mogla prodati u tom slučaju nije mogla biti ispod jedne trećine utvrđene vrijednosti (prij. čl. 97. st. 5. OZ-a 96).

(Već) Zakonom o izmjenama i dopunama Ovršnog zakona iz 1999. godine ${ }^{38}$ najniža prodajna cijena od četiri petine prema kojoj se nekretnina smjela prodati na prvom ročištu za dražbu, snižena je na tri četvrtine te je bila propisana i mogućnost treće prodaje nekretnine. Ako nekretnina nije bila prodana ni na drugom ročištu, sud je bio dužan u roku od najmanje 15 do najviše 30 dana zakazati (i) treće ročište na kojemu je nekretnina mogla biti prodana bez ograničenja najniže cijene u odnosu na utvrđenu vrijednost (čl. 21. ZIDOZ-a 99). Ta je mogućnost trećeg ročišta za dražbu, međutim, bila brisana ZIDOZ-om 03 (čl. 52. ZIDOZ-a 03). Najniža prodajna cijena od tri četvrtine prema kojoj se nekretnina smjela prodati na prvom ročištu za dražbu, dalje je snižena na dvije trećine ZIDOZ-om 05, dok je najniža prodajna cijena od jedne polovine po kojoj se nekretnina smjela prodati na drugom ročištu za dražbu, snižena na jednu trećinu (čl. 53. ZIDOZ-a 05). ${ }^{39}$

\subsection{OVRŠNI ZAKON IZ 2010. GODINE}

Novi (drugi) Ovršni zakon donesen je 23. studenoga 2010. godine,${ }^{40}$ paralelno sa Zakonom o javnim ovršiteljima. ${ }^{41}$ Ta dva Zakona trebala su biti osnova novog ovršnopravnog sustava u kojem su temeljnu ulogu trebali imati javni ovršitelji. Javni ovršitelji trebali su određivati i provoditi ovrhe na temelju ovršnih isprava, osim u slučajevima kada je određivanje i provedba ovrhe iznimno bila u (isključivoj) nadležnosti suda (čl. 9. st. 1. OZ-a 10). Javnoovršiteljska služba, međutim, nije bila započela s radom, ${ }^{42}$ a niti je OZ 10 - u najvećem dijelu svojih odredaba - ikada bio stupio na snagu. ${ }^{43}$ To je također vrijedilo i za odredbe OZ-a 10 o ovrsi na nekretnini (čl. 128. - čl. 177. OZ-a 10; čl. 340. OZ-a 10). ${ }^{44}$

38 Zakon o izmjenama i dopunama Ovršnog zakona iz 1999. godine, Narodne novine Republike Hrvatske, broj 29/1999 (u daljnjem tekstu: ZIDOZ 99).

Sniženjem najniže prodajne cijene nekretnine, među ostalim, nastojalo se motivirati ovršenike da se aktivno uključe u pronalaženje potencijalnih kupaca nekretnine. Bilo je naime ocijenjeno da dotadašnja pravila nisu motivirala ovršenike da se aktivno uključe u proces prodaje, nego suprotno pasivnost im je omogućavala da im nekretnine ostane u posjedu (zbog neuspjelih dražbenih ročišta). Tako Hrastinski Jurčec, Lj., op. cit. u bilj. 35, str. 22. Vidjeti i Čuveljak, J., op. cit. u bilj. 35, str. 108. Vidjeti i Konačni prijedlog Zakona o izmjenama i dopunama Ovršnog zakona iz 2005. godine, op. cit. u bilj. 35, obrazloženje uz čl. 53. ZIDOZ-a 05.

Ovršni zakon iz 2010. godine, Narodne novine Republike Hrvatske, broj 139/2010, s kasnijim izmjenama i dopunama: Narodne novine Republike Hrvatske, broj 125/2011, 150/2011, 154/2011, 12/2012, 70/2012, 80/2012 - v. Odluku Ustavnog suda Republike Hrvatske, broj: U-I-1988/2011 i dr. od 19. lipnja 2012. (u daljnjem tekstu: OZ 10).

41 Zakon o javnim ovršiteljima iz 2010. godine, Narodne novine Republike Hrvatske, broj 139/2010, s kasnijim izmjenama i dopunama: Narodne novine Republike Hrvatske, broj 150/2011, 70/2012, 112/2012.

42 Vidjeti Narodne novine Republike Hrvatske, broj 150/2011, 70/2012, 112/2012.

43 Vidjeti Narodne novine Republike Hrvatske, broj 150/2011, 154/2011, 12/2012, 70/2012.

44 Prvotno je bilo propisano, među ostalim, da će odredbe o ovrsi na nekretnini stupiti na snagu 1. siječnja 2012. godine (čl. 340. OZ-a 10), potom je rok bio pomaknut na 1. srpnja 2012. (čl. 2. Zakona o izmjenama Ovršnog zakona, Narodne novine Republike 
Unatoč tomu što odredbe o ovrsi na nekretnini OZ-a 10 nisu bile na snazi, radi sustavnosti potrebno je analizirati najznačajnija rješenja toga sustava u pogledu zaštite ovršenika, posebice specifičnosti i različitosti (ovršnopravnog) uređenja u odnosu na OZ 96.

Kao što je već navedeno, novine su se sastojale u propisivanju javnog ovršitelja kao općenadležnog ovršnog tijela u ovrsi na novčanoj tražbini (na nekretnini) (čl. 39. st. 1. OZ-a 10). ${ }^{45}$ Promatrajući položaj ovršenika u ovrsi na nekretnini te zaštitu nekretnine koja je služila za stanovanje, OZ $10^{46}$ bio je preuzeo rješenja OZ-a 96 , pa se u vezi s tim upućuje na ono što je rečeno supra ad 2.1. U odnosu na OZ 96, do promjena je bilo došlo u vezi s utvrđivanjem vrijednosti nekretnine, mogućeg broja dražbenih ročišta te najniže prodajne cijene.

Vrijednost nekretnine primarno se utvrđivala zaključkom o prodaji nakon ročišta na kojemu je strankama bilo omogućeno da se sporazumiju o vrijednosti te da prilože odgovarajuće pisane dokaze (čl. 139. st. 1. OZ-a 10), a podredno, ako se stranke nisu mogle sporazumjeti, na način da je ovršno tijelo utvrdilo njezinu vrijednost uz sudjelovanje stalnog sudskog vještaka odgovarajuće struke (čl. 139. st. 1. OZ-a 10).

Prodaja nekretnine obavljala se usmenom javnom dražbom (čl. 143. st. 1. OZ-a 10), dok se - kao i prema OZ-u 96 nakon ZIDOZ-a 05 - na prvom ročištu za dražbu nekretnina nije mogla prodati ispod dvije trećine utvrđene vrijednosti nekretnine, a na drugom ročištu za dražbu ispod jedne trećine njezine utvrđene vrijednosti (čl. 148. st. 1. i 2. OZ-a 10). Već se izmjenama i dopunama iz 2011. godine bilo interveniralo u odredbe o dražbenim ročištima i prodajnoj cijeni. Bila je (ponovno) uvedena mogućnost trećeg dražbenog ročišta ${ }^{47}$ te na drugom i trećem ročištu za dražbu nekretnina se nije mogla prodati ispod jedne polovine njezine utvrđene vrijednosti (čl. 4. Zakona o izmjenama i dopunama Ovršnog zakona iz 2011. godine $\left.{ }^{48}\right)^{49}$.

\section{3. $\mathrm{OZ} 12$}

\subsubsection{Općenito}

Donošenjem OZ-a 12 21. rujna 2012. godine zakonodavac se opredijelio za onaj ovršnopravni sustav kakav je bio uspostavljen OZ-om 96 i kakav se zapravo primjenjivao u praksi unatoč donošenju OZ-a 10.

Položaj i zaštita ovršenika u postupku ovrhe na nekretnini bila je uređena sve do donošenja ZIDOZ-a 14 na sadržajno jednak način kao i prema OZ-u 96, s time što je prema izvornom uređenju OZ-a 12 bila podignuta najniža prodajna cijena prema kojoj se nekretnina mogla

Hrvatske, broj 150/2011), da bi Zakonom o izmjenama Ovršnog zakona iz 2012. bio pomaknut na 15. listopada 2012. godine (Narodne novine Republike Hrvatske, broj 70/2012). Konačno, OZ-om 12 propisan je prestanak važenja OZ-a 10 (čl. 370. OZ-a 12).

Više o nadležnosti javnih ovršitelja prema OZ-u 10 v. Dika, M., Novine u Ovršnom zakonu iz 2010. s posebnim osvrtom na ovrhu na novčanim tražbinama, Aktualnosti hrvatskog zakonodavstva i pravne prakse: građansko, trgovačko, radno i procesno pravo u praksi, Godišnjak 18, 2011., str. 290.-292.

47 Mogućnost trećeg dražbenog ročišta postojala je već prema ZIDOZ-u 99. O tome v. supra ad 2.1.

48 Zakon o izmjenama i dopunama Ovršnog zakona iz 2011. godine, Narodne novine Republike Hrvatske, broj 125/2011. 
prodati na drugom dražbenom ročištu s jedne trećine na jednu polovinu utvrđene vrijednosti nekretnine (prij. čl. 102. st. 2. OZ-a 12).

Izmjenama i dopunama Ovršnog zakona iz 2014. godine propisano je sudjelovanje Financijske agencije u postupku ovrhe na nekretnini na način da se nekretnine prodaju na elektroničkoj javnoj dražbi koju provodi Agencija (čl. 95.a st. 1., čl. 97. st. 1, čl. 132.a - čl. 132.i OZ-a 12). Osim toga, tim su izmjenama i dopunama prihvaćena rješenja koja su već postojala u izvornoj varijanti OZ-a 96. Tako je propisano (ponovno) sudjelovanje ovlaštenog sudskog vještaka ili procjenitelja pri utvrđivanju vrijednosti nekretnine (čl. 92. OZ-a 12) te je najniža prodajna cijene na prvom dražbenom ročištu podignuta na onu vrijednost koju je imala u izvornom uređenju prema OZ-u 96: četiri petine utvrđene vrijednosti nekretnine (čl. 102. st. 1. OZ-a 12). Prema OZ-u 12 nakon ZIDOZ-a 14, na drugoj elektroničkoj javnoj dražbi nekretnina se ne može prodati ispod tri petine utvrđene vrijednosti nekretnine (čl. 102. st. 2. OZ-a 12).

Dok je prema izvornom uređenju OZ-a 96 ovršenik mogao u roku od osam dana od dana dostave rješenja o ovrsi na nekretnini predložiti da se ovrha odredi na drugom predmetu ovrhe, prema OZ-u 12 nakon ZIDOZ-a 14 ovršenik je mogao uz ispunjenje sličnih pretpostavaka tražiti odgodu ovrhe. O odgodi ovrhe prema OZ-u 12 nakon ZIDOZ-a 14 v. infra ad 2.3.2. Uz mogućnost da ovršenik traži odgodu ovrhe, ZIDOZ-om 14 bile su unesene u OZ 12 specifičnosti u vezi s iseljenjem ovršenika iz prodane nekretnine u kojoj je on stanovao i koja je bila nužna za zadovoljenje njegovih osnovnih stambenih potreba te osoba koje je po zakonu dužan uzdržavati (v. infra ad 2.3.3.).

\subsubsection{Odgoda ovrhe na nekretnini na prijedlog ovršenika}

Uz opća pravila o odgodi ovrhe, ${ }^{50}$ u Zakon iz 2012. ZIDOZ-om 14 bile su unesene posebne odredbe o odgodi ovrhe na nekretnini, i to nekretnini u kojoj je ovršenik stanovao i koja je bila nužna za zadovoljenje njegovih osnovnih stambenih potreba te osoba koje je po zakonu bio dužan uzdržavati.

Prema prij. čl. 84.a st. 1. OZ-a 12, ovršenik je mogao u roku od osam dana od dana dostave rješenja o ovrsi na nekretnini u kojoj je stanovao i koja je bila nužna za zadovoljenje njegovih osnovnih stambenih potreba i osoba koje je prema zakonu dužan uzdržavati predložiti sudu odgodu ovrhe. Ovršenik je uz prijedlog bio dužan priložiti dokaz o postojanju svog imovinskog, odnosno materijalnog prava čijom je raspoložbom u cijelosti mogao namiriti tražbinu ovrhovoditelja. Sud je taj prijedlog bio dužan dostaviti bez odgode ovrhovoditelju, koji se o njemu mogao očitovati u roku od osam dana od dana dostave (prij. čl. 84.a st. 2. OZ-a 12). Nakon primitka očitovanja ovrhovoditelja ili nakon isteka roka za očitovanje, sud je donosio rješenje o prijedlogu (prij. čl. 84.a st. 3. OZ-a 12).

Sud je bio dužan prihvatiti prijedlog ovršenika ako je stekao uvjerenje (1) da je nekretnina predstavljala nekretninu u kojoj je ovršenik stanovao i koja je nužna za zadovoljenje njegovih osnovnih stambenih potreba i osoba koje je po zakonu dužan uzdržavati, te (2) da se tražbina ovrhovoditelja u cijelosti mogla namiriti iz sredstava dobivenih na temelju raspolaganja imovinskim, odnosno materijalnim pravom ovršenika (prij. čl. 84.a st. 4. OZ-a 12). Pritom ako 
je ovršenik priložio kao dokaz postojanje svog prava na novčanoj tražbini, sud je bio dužan prihvatiti prijedlog ovršenika ako je stekao uvjerenje da će ovršenik namiriti tražbinu ovrhovoditelja u roku od jedne godine od donošenja rješenja o odgodi ovrhe (prij. čl. 84.a st. 6. OZ-a 12). Sud nije prihvaćao prijedlog ovršenika ako je ocijenio da bi se zbog toga ovrha znatnije oduljila ili otežala, odnosno ako je ovrhovoditelj zbog toga mogao trpjeti znatniju štetu (prij. čl. 84.a st. 5. OZ-a 12).

Ako je sud prihvatio prijedlog ovršenika, zabilježba ovrhe u zemljišnoj knjizi ostajala bi do potpunog namirenja tražbine ovrhovoditelja (prij. čl. 84.a st. 7. OZ-a 12). Ako ovršenik u roku određenom rješenjem nije uplatio u sudski polog sredstva za namirenje tražbine ovrhovoditelja u cijelosti, sud je dužan nastaviti ovrhu na temelju rješenja o ovrsi na nekretnini (prij. čl. 84.a st. 8. OZ-a 12).

Citirane su odredbe prij. čl. 84.a OZ-a 12 brisane posljednjim izmjenama i dopunama OZ-a 12 iz 2017. godine (čl. 16. ZIDOZ-a 17). ${ }^{51}$ Napuštanje rješenja prij. čl. 84.a OZ-a 12 i ne čudi uzme li se u obzir da su citirane odredbe bile dvojbene zbog više razloga. Nije naime razumno da će ovrhovoditelj zahtijevati ovrhu na nekretnini ako svoju tražbinu može namiriti iz drugih predmeta ovrhe, odnosno dijelova imovine ovršenika u odnosu na koje je ovrha jeftinija, brža te jednostavnija, a time i učinkovitija (npr. ovrha na novčanoj tražbini ovršenika, posebice novčanoj tražbini po računu). Ako bi to i bio slučaj, sud je uvijek imao na raspolaganju odredbu čl. 6. OZ-a 12 o zaštiti dostojanstva ovršenika. Stoga je razumno pretpostaviti da ovrhovoditelj zahtijeva ovrhu na nekretnini jer je to jedini mogući način da ostvari svoju tražbinu; dakle, ovršenik nema drugih dijelova imovine na kojoj bi se ovrha mogla provesti (te se može pretpostaviti da to neće biti slučaj niti u bliskoj budućnosti, a posebice u roku od jedne godine od donošenja rješenja o odgodi ovrhe (prij. čl. 84.a st. 6. OZ-a 12)). Odgađanjem ovrhe na nekretnini u takvim uvjetima poskupljuje postupak te stavlja ovršenika u (još) gori položaj; tražbina koju će konačno morati ispuniti bit će (mnogo) veća. Pritom se, naravno, i ovrhovoditelj stavlja u nezavidnu situaciju. Zbog toga je više nego dvojbeno rješenje koje se predlagalo u P ZIDOZ-u iz listopada 2016., a prema kojemu bi odgoda ovrhe, mimo općih pravila o odgodi na prijedlog ovršenika, bila dopuštena i onda kada ovršenik i članovi njegova kućanstva, u smislu propisa o socijalnoj skrbi, nemaju dovoljno sredstava za plaćanje najamnine za odgovarajući stambeni prostor $\mathrm{u}$ istoj ili susjednoj jedinici lokalne samouprave, niti ih mogu ostvariti svojim radom, primitkom od imovine, od obveznika uzdržavanja ili na drugi način (čl. 14. P ZIDOZ-a iz listopada 2016). Ovdje se (pak) izravno priznalo da ovršenik nema druge imovine na kojoj bi se potencijalno mogla provesti ovrha. Time bi se institut odgode ovrhe, među ostalim, pretvorio u mjeru socijalne politike.

U primjeni odredaba prij. čl. 84.a OZ-a 12, u literaturi se otvorilo (i) pitanje roka u kojem je ovršenik mogao tražiti odgodu ovrhe ${ }^{52}$ te dokaznog standarda. Naime, kakva je to razina "uvjerenosti" suda koja je bila potrebna glede postojanja pretpostavaka za određivanje odgode ovr-

51 Odredbe prij. čl. 84.a OZ-a 12 o odgodi ovrhe na nekretnini na prijedlog ovršenika primjenjuju se i nakon donošenja ZIDOZ-a 17 na one postupke koji su pokrenuti prije stupanja na snagu ZIDOZ-a 17 (v. čl. 44. st. 1., čl. 47. ZIDOZ-a 17), naravno, ako je još moguće podnijeti prijedlog u postupku (v. prij. čl. 84.a. st. 1. OZ-a 12).

52 Vodile su se rasprave o tome bi li sud mogao prihvatiti prijedlog za odgodu ovrhe koji je podnesen i u onom ovršnom postupku gdje je rješenje o ovrsi bilo doneseno prije 1. rujna 2014. godine. Prema prijelaznim i završnim odredbama ZIDOZ-a 14, naime, mogućnost da ovršenik podnese prijedlog za odgodu ovrhe primjenjivala se na one postupku koji su 1. rujna 2014. bili u tijeku i ako na taj dan nije bila započeta radnja na koju se prijedlog odnosio (čl. 82. st. 2. ZIDOZ-a 14). Vidjeti Jelinović, V., Ovrha na nekretninama od 1. 1. 2015., Financije, pravo i porezi, br. 3, 2015., str. 173. 
he? Je li to razina "vjerojatnosti” koju već poznaje OZ $12^{53}$ ili razina "ozbiljne vjerojatnosti" ${ }^{4}$ ili pak blaži oblik vjerojatnosti? ${ }^{55}$ Uzimajući u obzir razinu dokaznog standarda koji se zahtijeva općenito kod instituta odgode ovrhe prema OZ-u 12, trebalo je uzeti da je riječ o "vjerojatnosti”. Time se, naravno, ne umanjuje okolnost da je zakonodavac pri donošenju ZIDOZ-a 14 trebao jasnije propisati razinu dokaznog standarda na kojoj je sud trebao steći uvjerenje o postojanju pretpostavaka za ovaj vid odgode ovrhe. Osim toga, dvojbeno je bilo i značenje nekretnine "u kojoj ovršenik stanuje i koja je nužna za zadovoljenje njegovih osnovnih stambenih potreba i osoba koje je po zakonu dužan uzdržavati” (prij. čl. 84.a st. 1. i 4. t. 1. OZ-a 12). I dok bi se stanovanje moglo u pravilu povezivati s potvrdom o prebivalištu/boravištu te mjestom zaposlenja (i drugim sadržajima: vrtić/škola, primarna zdravstvena zaštita), dvojbeno je bilo kako mjeriti nužni stambeni prostor. ${ }^{56}$ Riječ je svakako o pravnom standardu, a s obzirom na to da su odredbe prij. čl. 84.a OZ-a 12 kratko bile na snazi teško da se i odgovarajuća sudska praksa mogla razviti. Također, upitno je i koliko je odgoda ovrhe zbog toga mogla trajati te je li ju bilo moguće odrediti i više puta..$^{57,58}$

\subsubsection{Gubitak prava na posjed te iseljenje ovršenika}

Prema OZ-u 12 nakon ZIDOZ-a 14, ako je prodana nekretnina predstavljala nekretninu u kojoj je ovršenik stanovao i koja je bila nužna za zadovoljenje osnovnih stambenih potreba ovršenika i osoba koje je po zakonu dužan uzdržavati, ovršenik je imao pravo korištenja nekretnine kao najmoprimac godinu dana od dana donošenja zaključka o predaji nekretnine (prij. čl. 127. st. 2. OZ-a 12). Prijedlog za korištenje nekretnine kao najmoprimac ovršenik je mogao podnijeti u roku od osam dana od dana primitka rješenja o ovrsi (prij. čl. 127. st. 3. OZ-a 12). Ako je ovrhovoditelj, međutim, osigurao drugu nekretninu za korištenje koja je bila dovoljna za zadovoljenje osnovnih stambenih potreba ovršenika i osoba koje je po zakonu bio dužan uzdržavati, u trajanju od godinu dana od dana donošenja zaključka o predaji nekretni-

53 Vidjeti, primjerice, čl. 17. st. 14., čl. 65. st. 1., čl. 67. st. 1., čl. 71. st. 2., čl. 118. st. 3., čl. 263. st. 7., čl. 329., čl. 330. st. 5., čl. 332. st. 2., čl. 333. st. 3., čl. 338. st. 1. t. 2., čl. 344. st. 1. i 2., čl. 346. st. 1., čl. 349. st. 1. i 2. OZ-a 12.

54 Prema Dika, M., O noveli Ovršnog zakona od 15. srpnja 2014., Pravo u gospodarstvu, vol. 54, br. 5, 2015., str. 1170., sudac je trebao uvjerenje o postojanju pretpostavaka za odgodu ovrhe prema prij. čl. 84.a OZ-a formirati na razini "ozbiljne vjerojatnosti".

55 Prema Mihelčić, G., u suradnji s Kontrec, D., Komentar Ovršnog zakona s opsežnom sudskom praksom i abecednim kazalom pojmova, Organizator, Zagreb, 2015., str. 390., čini se da je bila riječ o nižem stupnju uvjerenja nego što je slučaj kada OZ 12 traži da se neka pretpostavka učini vjerojatnom. Tako i Mihelčić, G., Novosti u ovrsi na nekretnini, Pravo i porezi, br. 10, 2014., str. 11.

56 Prema, npr., prij. čl. 10. Pravilnika o odobravanju pomoći za uzdržavanje u obliku zajma, mjerila i obilježja stana potrebnog za zadovoljavanje osnovnih stambenih potreba samca ili obitelji i o odobravanju pomoći iz socijalne skrbi (Narodne novine Republike Hrvatske, broj 28/1998, 117/2000, 81/2004), "Mjerila i obilježja stana potrebnog za zadovoljavanje osnovnih potreba samca ili obitelji za odobravanje pomoći za potrebe troškova stanovanja su: - za samca garsonijera ili jednosobni stan do površine $25 \mathrm{~m}^{2}$, - za dvočlanu obitelj jednosobni ili jednoipolsobni stan do površine $35 \mathrm{~m}^{2}$, - za tročlanu obitelj jednoipolsobni ili dvosobni stan do površine $45 \mathrm{~m}^{2}$, - za četveročlanu obitelj dvosobni ili trosobni stan do površine $55 \mathrm{~m}^{2}$. Ako obitelj ima više od četiri člana, na svakog člana obitelji dodaje se još $5 \mathrm{~m}^{2}$ stana." Citirana mjerila trebala su služiti jedinicama lokalne samouprave odnosno Gradu Zagrebu pri procjeni je li korisnik imao pravo na pomoć za podmirenje troškova stanovanja, među ostalim, najamnine (v. čl. 34. - čl. 39. Zakona o socijalnoj skrbi iz 1997. godine, Narodne novine Republike Hrvatske, broj 73/1997, 27/2001, 59/2001, 82/2001, 103/2003, 44/2006, 79/2007).

57 OZ-om 12 nakon ZIDOZ-a 14 bio je propisan rok od jedne godine od donošenja rješenja o odgodi ovrhe za namirenje tražbine ovrhovoditelja ali (samo) ako je ovršenik bio priložio kao dokaz postojanje svog prava na novčanoj tražbini (v. prij. čl. 84.a st. 6. OZ-a 12).

58 Ne iznenađuje stoga podatak da odgoda ovrhe prema prij. čl. 84.a OZ-a 12 nije našla svoju primjenu u praksi. Usp. Kontrec, D., op. cit. u bilj. 6 , str. 60 . 
ne, sud je bio dužan odbiti prijedlog ovršenika za korištenje prodane nekretnine kao najmoprimac (prij. čl. 127. st. 5. OZ-a 12).

Ako je ovršenik imao pravo korištenja nekretnine kao najmoprimac, bio je dužan kupcu od dana donošenja zaključka o predaji nekretnine do predaje nekretnine plaćati najamninu. Ako se kupac i ovršenik nisu mogli sporazumjeti o visini najamnine, visinu najamnine utvrđivao je sud $\mathrm{u}$ istom ovršnom postupku prema tržišnim cijenama u mjestu u kojem se nekretnina nalazila (prij. čl. 127. st. 4. OZ-a 12).

I prije nego što su citirane odredbe prij. čl. 127. st. 2. - 5. OZ-a 12 našle svoju primjenu u praksi brisane su ZIDOZ-om 17 (čl. 18. ZIDOZ-a 17). ${ }^{59},{ }^{60}$ Napuštanje rješenja o pravu ovršenika da koristi nekretninu koja je prodana u ovršnom postupku godinu dana od dana donošenja zaključka o predaji nekretnini svakako treba odrediti kao pozitivan korak u pravcu jačanja pravne sigurnosti u ovrsi na nekretninama. Odredbe prij. čl. 127. st. 2. - 5. OZ-a 12, naime, otvorile su brojna pitanja, među ostalim, odnosa kupca nekretnine u ovršnom postupku i ovršenika, posebice u slučaju nemogućnosti ili protivljenja ovršenika da plaća najamninu te mogućnosti kupca nekretnine da zahtijeva iseljenje ovršenika (prijašnjeg vlasnika nekretnine) protekom godine dana. ${ }^{61}$ Unatoč tomu što je OZ 12 koristio izraz "najmoprimac" te "najamnina”, nije bila riječ o klasičnom najamnom odnosu budući da je pravo ovršenika da ostane u nekretnini bilo uređeno s ius cogens. ${ }^{62}$ Tu je zapravo, čini se, bila riječ o svojevrsnom pravu na nužni smještaj čiji je teret (u načelu) država prebacila na kupce nekretnine te ovrhovoditelja. ${ }^{63}$ Također, i tu bi vrijedilo i ono što je supra ad 2.3.2. rečeno o pravnom standardu "nekretnine u kojoj ovršenik stanuje i koja je nužna za zadovoljenje njegovih osnovnih stambenih potreba i osoba koje je po zakonu dužan uzdržavati" (prij. čl. 127. st. 2. OZ-a 12). Tomu treba svakako pridodati i negativan utjecaj citiranih odredaba prij. čl. 127. st. 2. - 5. OZ-a 12 uopće na ovršnu prodaju nekretnine. Naime, nije se moglo ni očekivati da bi se netko usudio kupiti nekretninu u neizvjesnosti hoće li pro futuro morati pokretati sudski postupak radi iseljenja ovršenika, odnosno bivšeg vlasnika nekretnine.

59 Među ostalim, u Obrazloženju KP ZIDOZ-a iz travnja 2017. navodi se kao razlog brisanja odredaba prij. čl. 127. st. 2. - 5. OZ-a 12 okolnost da pravo ovršenika koristiti nekretninu koja je prodana u ovršnom postupku godinu dana od donošenja zaključka o predaji nekretnini “nije zaživjelo u praksi.”. V. Obrazloženje uz čl. 18. i čl. 19. KP ZIDOZ-a iz travnja 2017. Uz to, treba uzeti u obzir da je rok u kojem je ovršenik mogao podnijeti prijedlog za korištenje nekretnine kao najmoprimca iznosio osam dana od dana primitka rješenja o ovrsi (prij. čl. 127. st. 3. OZ-a 12). Podnošenje prijedloga značilo bi i svojevrsni "pristanak" ovršenika na ovršnu prodaju nekretnine te iseljenje i predaju nekretnine. U praksi, s druge strane, svakodnevno svjedočimo slučajevima "prisilnih deložacija" ovršenika i njihovih obitelji.

60 Odredbe prij. čl. 127. st. 2. - 5. OZ-a 12 o pravu na korištenje prodane nekretnine kao najmoprimac na prijedlog ovršenika primjenjuju se i nakon donošenja ZIDOZ-a 17 na one postupke koji su pokrenuti prije stupanja na snagu ZIDOZ-a 17 (v. čl. 44. st. 1., čl. 47. ZIDOZ-a 17), naravno, ako je još moguće podnijeti prijedlog u postupku (v. prij. čl. 127. st. 3. OZ-a 12).

61 Usp. Dika, M., O Noveli..., op. cit. u bilj. 54, str. 1184.; Mihelčić, G., Novosti..., op. cit. u bilj. 55, str. 13. - 14.

62 Ovršenik je imao pravo izbora koje je vršio podnošenjem prijedloga za korištenje nekretnine kao najmoprimca (arg. ex prij. čl. 127. st. 3. OZ-a 12), s druge strane, novi vlasnik nekretnine nije imao izbora u pogledu stupanja u "najamni odnos" s ovršenikom (arg. ex prij. čl. 127. st. 4. OZ-a 12) (unatoč tomu što se moglo tvrditi da mu je bilo poznato pod kojim je uvjetima bio kupio nekretninu u postupku ovrhe - arg. ex: prij. čl. 127. st. 3. u vezi s čl. 98. st. 1. OZ-a 12).

63 Ako ovršenik nije plaćao najamninu, novi vlasnik-kupac morao je, čini se, pokretati ovršni postupak radi plaćanja najamnine s vrlo velikom vjerojatnošću da neće moći ostvariti svoju tražbinu dužne najamnine. U pravilu je i do ovrhe i ovršne prodaje nekretnine ovršenika i bilo došlo jer se prvotni ovrhovoditelj nije mogao namiriti od ovršenika. 


\section{EUROPSKI SUD ZA LJUDSKA PRAVA: PREDMET VASKRSIĆ PROTIV SLOVENIJE}

\section{1. ČINJENIČNI OPIS PREDMETA}

U predmetu Vaskrsić protiv Slovenije podnositelj zahtjeva istaknuo je povredu čl. 1. Protokola 1. uz EK, a do koje je došlo ovršnom prodajom njegove kuće na javnoj dražbi. ${ }^{64}$ Sažeto, protiv podnositelja zahtjeva bili su u tijeku ovršni postupci pokrenuti od triju različitih ovrhovoditelja. ${ }^{65}$ Iako je prvi ovrhovoditelj inicijalno predlagao ovrhu na nekretnini podnositelja zahtjeva, njegova je tražbina naknadno bila namirena novčanim sredstvima s računa podnositelja zahtjeva. ${ }^{66}$ Drugi ovrhovoditelj, nakon neuspješne ovrhe na pokretninama, predložio je također ovrhu na nekretnini. Kuća je i bila prodana na javnoj dražbi radi namirenja tražbine drugog ovrhovoditelja. U međuvremenu, podnositelj prijedloga namirio je tražbinu prema drugom ovrhovoditelju stoga je u odnosu na drugog ovrhovoditelja ovršni postupak bio obustavljen. ${ }^{67}$ Treći ovrhovoditelj, međutim, pridružio se postupku ovrhe na nekretnini sa svojim zahtjevom za namirenje tražbine nakon što je kuća bila dosuđena kupcu. Iz cijene postignute ovršnom prodajom kuće, namiren je treći ovrhovoditelj, također, i porezi te tražbina osigurana hipotekom na kući. ${ }^{68}$

Ovrha na nekretnini predložena je radi namirenja tražbine drugog ovrhovoditelja čija glavnica je iznosila 124 eura, uz zakonske kamate na taj iznos te troškove postupka. ${ }^{69} \mathrm{U}$ okviru postupka bila je izvršena procjena vrijednosti nekretnine te je nekretnina bila procijenjena na iznos od 140.000 eura. ${ }^{70}$ Između prve i druge dražbe, drugi ovrhovoditelj predložio je sudu promjenu predmeta ovrhe, i to na novčana sredstva na računu podnositelja zahtjeva i njegovoj plaći. ${ }^{71}$ Međutim, na drugom dražbenom ročištu kuća podnositelja zahtjeva prodana je za 70.000 eura, odnosno $50 \%$ od procijenjene vrijednosti nekretnine. ${ }^{72}$ Tri dana nakon donošenja odluke o dosudi nekretnine kupcu, sud je prihvatio prijedlog drugog ovrhovoditelja te odredio ovrhu na plaći i bankovnom računu podnositelja zahtjeva, obrazlažući u svojoj odluci da je prethodna ovrha na pokretninama bila neuspješna te uopće ne spominjući da je određena ovrha na nekretnini. Bilo je utvrđeno da se 2/3 plaće koju podnositelj zahtjeva prima od poslodavca može ovršiti, osiguravajući da podnositelju zahtjeva ostane zaštićeni zakonski minimum. ${ }^{73}$

\footnotetext{
64 Podnositelj je istaknuo i povredu čl. 13. EK-a o pravu na djelotvorni pravni lijek. Za potrebe rada, analiza će obuhvati dijelove Presude koji se odnose na povrede čl. 1. Protokola 1. uz EK.

65 Za potrebe rada, označavat će se kao prvi, drugi i treći ovrhovoditelj.

66 Presuda Vaskrsić protiv Slovenije, op. cit. u bilj. 12, str. 2.

67 Ibid., str. 2., 5.

68 Loc. cit.

69 Ibid., str. 2.-3.

$70 \quad$ Ibid., str. 3.-4.

71 Ibid., str. 4.

72 Ibid., str. 5.

73 Loc. cit.
} 
Treći ovrhovoditelj čija je tražbina zajedno s troškovima i kamatama iznosila ukupno 5.112 eura pridružio se postupku ovrhe na kući podnositelja zahtjeva. ${ }^{74}$

Podnositelj zahtjeva podnio je žalbu protiv odluke o dosudi nekretnine te je, među ostalim, obavijestio sud da je namirio tražbinu drugog ovrhovoditelja. Među ostalim, istaknuo je da je bio u financijskim problemima tijekom te godine te ako se ne ukine odluka, on i njegova obitelj (potencijalno) postat će beskućnici. Budući da je podnositelj zahtjeva namirio tražbinu drugom ovrhovoditelju, istog je dana drugi ovrhovoditelj povukao ovršni prijedlog te je sud obustavio postupak ovrhe prema drugom ovrhovoditelju. ${ }^{75}$

Nakon što je podnositelj zahtjeva namirio drugog ovrhovoditelja, sud je prihvatio prijedlog trećeg ovrhovoditelja za pridruživanje postupku ovrhe na nekretnini a koji se vodio u povodu prijedloga drugog ovrhovoditelja. Protiv te sudske odluke podnositelj zahtjeva podnio je prigovor ističući da je ovršni postupak na nekretnini pokrenut od drugog ovrhovoditelja obustavljen te da želi da se tražbina trećeg ovrhovoditelja namiri iz njegovih novčanih sredstava u sljedećih dvanaest mjeseci. Sud je, međutim, odbio njegov prigovor, kao i mogućnost da se ovrha odredi na novčanim sredstvima podnositelja zahtjeva. ${ }^{76}$ Također, podnositelj zahtjeva nije uspio ni sa žalbom protiv odluke o dosudi nekretnine kupcu. ${ }^{77}$

Nakon plaćanja kupovne cijene, sud je odredio predaju prodane nekretnine na javnoj dražbi kupcu, kao i da se podnositelj zahtjeva mora u roku od 30 dana iseliti iz prodane nekretnine. ${ }^{78}$ Podnositelj zahtjeva podnio je i žalbu protiv odluke o predaji nekretnine, ali s njom nije uspio. ${ }^{79}$

Nakon ročišta za diobu, sud je odredio namirenje tražbina trećeg ovrhovoditelja u iznosu od 146 te 5.895 eura, poreza na promet nekretnine u iznosu od 1.372 eura te tražbine koja je bila osigurana hipotekom na toj nekretnini u iznosu od 58.888 eura. Ostatak od prodajne cijene u iznosu od 3.699 eura prenesen je na račun podnositelj zahtjeva. ${ }^{80}$

U međuvremenu, podnositelj zahtjeva podnio je i ustavnu tužbu, ističući da je odluka suda bila nezakonita i arbitrarna te da prodaja njegove kuće radi namirenja duga od 124 eura predstavlja nerazmjerno miješanje u njegovo pravo vlasništva. ${ }^{81}$ Ustavna tužba, međutim, bila je odbijena. ${ }^{82}$ Konačno, podnositelj zahtjeva i njegova obitelj bili su prisilno iseljeni iz prodane kuće. ${ }^{83}$

$\begin{array}{ll}74 & \text { Loc. cit. } \\ 75 & \text { Loc. cit. } \\ 76 & \text { Ibid., str. 6. } \\ 77 & \text { Loc. cit. } \\ 78 & \text { Loc. cit. } \\ 79 & \text { Ibid., str. 6.-7. } \\ 80 & \text { Ibid., str. 7. } \\ 81 & \text { Ibid., str. 7.-8. } \\ 82 & \text { Ibid., str. 8. } \\ 83 & \text { Loc. cit. }\end{array}$




\subsection{STAV SUDA}

Podnositelj zahtjeva istaknuo je da ovršna prodaja nekretnine radi namirenja tražbine ovrhovoditelja koja je iznosila 124 eura predstavlja povredu čl. 1. Protokola 1. uz EK. ${ }^{84}$ Prvo, kuća se ne bi smjela prodati radi namirenja tako male tražbine. ${ }^{85}$ Osim toga, podnositelj zahtjeva je istaknuo da sud nije postupao s dužnom pažnjom (diligence) pri određivanju predmeta ovrhe. ${ }^{86}$

Sud je utvrdio - kao i prema dosadašnjoj praksi ${ }^{87}$ - da ovršna prodaja nekretnine predstavlja miješanje u pravo podnositelja zahtjeva na mirno uživanje vlasništva. ${ }^{88}$ Potom je sud ispitao daljnje pretpostavke, i to je li miješanje propisano zakonom te ima li legitiman cilj. Sud je našao da je miješanje u pravo podnositelja bilo utemeljeno na zakonu (Ovršnom zakonu) te da je imalo legitiman cilj: zaštiti vjerovnike. ${ }^{89}$

Razmatrajući je li miješanje bilo razmjerno legitimnom cilju, Sud je istaknu da pravo na mirno uživanje vlasništva mora postići pravičnu ravnotežu (fair balance) između zahtjeva općeg interesa i zahtjeva za zaštitom individualnih ljudskih prava. ${ }^{90}$ Osim toga, mora postojati prikladan odnos razmjernosti između mjere koja je primijenjena te cilja koji se nastoji postići. ${ }^{91} \mathrm{U}$ svakom slučaju, sud mora cijeniti da li mjerama državne intervencije odnosna osoba mora trpjeti neproporcionalan te pretjeran teret. ${ }^{92}$ Pritom sud priznaje da država uživa široku slobodu procjene kako s obzirom na predmet ovrhe tako i s obzirom na okolnost jesu li posljedice ovrhe opravdane u općem interesu s obzirom na cilj koji se nastoji postići. ${ }^{93}$

Iako relevantni slovenski Ovršni zakon ne predviđa redoslijed predmeta ovrhe kojim bi se ovrhovoditelj trebao koristiti, posebice u slučaju očite nerazmjernosti između iznosa tražbine koja se ostvaruje te predmeta ovrhe, niti ne određuje iznos tražbine ispod kojega se nekretnina ne može prodati u ovršnom postupku, Sud smatra da su nadležni sudovi trebali pažljivo razmotriti mogućnost drugih odgovarajućih ali manje tegobnih alternativa, uzimajući u obzir važnost ovrhe na nekretnini koja je predstavlja "dom" podnositelja zahtjeva. ${ }^{94}$ Osim toga, sud je istaknuo da je ovrha na novčanim sredstvima po računu podnositelja zahtjeva bila potencijalno prikladna i učinkovita mjera za namirenje tražbine ovrhovoditelja. ${ }^{95}$

\footnotetext{
84 Ibid., str. 13.

85 Ibid., str. 14.

86 Ibid., str. 15.

87 Europski sud za ljudska prava: predmet Zehenter protiv Austrije, presuda od 16. srpnja 2009., dostupno na: URL=http://hudoc. echr.coe.int/eng\#\{“appno”:[“20082/02"],"itemid”:[“001-93594”]\}; predmet Rousk protiv Švedske, presuda od 25. srpnja 2013. dostupno na: URL=http://hudoc.echr.coe.int/eng\#\{“ecli”:[“2013:0725JUD 00 2718304”],"itemid”:[“001-123422”]\}. Pristupljeno 19. srpnja 2017.

88 Presuda Vaskrsić protiv Slovenije, op. cit. u bilj. 12, str. 17.

89 Ibid., str. 17.-18.

$90 \quad$ Ibid., str. 18.

91 Loc. cit.

92 Loc. cit.

93 Loc. cit.

94 Ibid., str. 20.

95 Ibid., str. 20.-21.
} 
Uzimajući u obzir, dakle, malu vrijednost tražbine ovrhovoditelja koja se ostvarivala ovršnom prodajom nekretnine te propust nadležnih sudova da razmotre druge prikladne ali manje tegobne mjere, Sud je zaključio da je država propustila postići pravičnu ravnotežu između cilja koji se nastojao postići i mjere koja je primijenjena u ovršnom postupku koji se vodio protiv podnositelja zahtjeva.

\section{ZAŠTITA OVRŠENIKA PREMA OZ-U 12 NAKON ZIDOZ-A 17}

\subsection{OPĆENITO}

ZIDOZ 17 druga je po redu novela kojom se značajnije interveniralo u postupak ovrhe na nekretnini nakon donošenja OZ-a 12 u cilju zaštite položaja ovršenika, a u svjetlu stava Europskog suda u predmetu Vaskrsić protiv Slovenije.

Prvo, interveniralo se u odredbe čl. 75. OZ-a 12 o zaštiti ovršenika fizičke osobe (koja ne obavlja registriranu djelatnost) propisivanjem jedine nekretnine u kojoj stanuje ovršenik kao nekretnine nužne za zadovoljenje osnovnih životnih potreba ovršenika i osoba koje je po zakonu dužan uzdržavati (nov. čl. 75. st. 5. - 8. OZ-a 12; čl. 12. ZIDOZ-a 17). Potom, propisani su posebni uvjeti za određivanje ovrhe na nekretnini kojima je ovrha na nekretnini (neovisno o tome je li ona jedina nekretnina ovršenika nužna za zadovoljenje osnovnih životnih potreba) u načelu isključenja do određene visine tražbine ovrhovoditelja, a preko toga iznosa propisuje se primjena kriterija "pravične ravnoteže" (nov. čl. 80.b OZ-a 12; čl. 15. ZIDOZ-a 17). Treće, kao što je već navedeno, brisane su odredbe prij. čl. 84.a OZ-a 12 o odgodi ovrhe na prijedlog ovršenika u slučaju kada je ona određena na nekretnini u kojoj ovršenik stanuje i koja je nužna za zadovoljenje njegovih osnovnih stambenih potreba i osoba koje je po zakonu dužan uzdržavati (čl. 16. ZIDOZ-a 17), te odredbe prij. čl. 127. st. 2. - 5. OZ-a 12 o pravu ovršenika da koristi nekretninu kao najmoprimac godinu dana od dana donošenja zaključka o predaji nekretnine (čl. 18. ZIDOZ-a 17). ${ }^{96}$ Konačno, u OZ 12 unesene su odredbe o "stambenom zbrinjavanju ovršenika” (nov. čl. 131.a - čl. 131.c OZ-a 12; čl. 20. ZIDOZ-a 17).

\subsection{ZAŠTITA OVRŠENIKA FIZIČKE OSOBE}

Prema OZ-u nakon ZIDOZ-a 17, smatra se da je jedina nekretnina u kojoj stanuje ovršenik koji ne obavlja registriranu djelatnost nužna za zadovoljenje osnovnih životnih potreba ovršenika i osoba koje je po zakonu dužan uzdržavati, osim ako je ovršenik u trenutku sklapanja pravnog posla kojim preuzima obvezu izjavio da je suglasan da se radi namirenja ovrhovoditeljeve tražbine ovrha može provesti na njegovoj jedinoj nekretnini (nov. čl. 75. st. 5. reč. 1. OZ-a 12). Suglasnost da se radi namirenja ovrhovoditeljeve tražbine ovrha može provesti na jedinoj nekretnini ovršenika daje se u pisanu obliku i ima učinak ako je potpis ovršenika ovjerio javni bilježnik ili koja druga osoba ili tijelo s javnim ovlastima (nov. čl. 75. st. 5. reč. 2. OZ-a 12). Ta 
suglasnost vrijedi ako dođe do promjene vjerovnika ili ako ovršenik stekne novu nekretninu (nov. čl. 75. st. 5. reč. 3. OZ-a 12). ${ }^{97},{ }^{98}$

U citiranoj odredbi nov. čl. 75. st. 5. reč. 1. OZ-a 12, dakle, sadržane su pretpostavke pod kojima će se smatrati da je nekretnina u kojoj stanuje ovršenik koji ne obavlja registriranu djelatnost nužna za zadovoljenje njegovih osnovnih životnih potreba te osoba koje je po zakonu dužan uzdržavati. To će biti ona nekretnina u kojoj on stanuje i osobe koje je po zakonu dužan uzdržavati, a u odnosu na koju ovršenik nije dao suglasnost da se radi namirenja ovrhovoditeljeve tražbine može provesti ovrha (arg. ex nov. čl. 75. st. 5. reč. 1. OZ-a 12). Dvojbeno je, međutim, određenje prema kojemu potpis ovršenika na suglasnosti, uz javnog bilježnika, može ovjeriti "druga osoba ili tijelo s javnim ovlastima" (nov. čl. 75. st. 5. reč. 2. OZ-a 12). Otvoreno je pitanje koje bi to drugo tijelo ili osoba s javnim ovlastima bilo, uzme li se u obzir da je ovjera (legalizacija) potpisa u nadležnosti javnih bilježnika. ${ }^{99}$

Treba primijetiti, također, da suglasnost vrijedi i u slučaju promjene vjerovnika (do koje bi, npr., došlo zbog ustupa tražbine) ili ako ovršenik stekne novu nekretninu. Pritom nije jasno na što bi se sve odnosilo ovo potonje: odnosi li se samo na slučajeve kad ovršenik, osim nekretnine u odnosu na koju je dao suglasnost, naknadno stekne i drugu nekretninu (u tom slučaju obje se ne bi smatrale nužne za zadovoljenje njegovih osnovnih životnih potreba i osoba koje je po zakonu dužan uzdržavati) ili pak i na slučajeve kada bi ovršenik otuđio nekretninu u odnosu na koju je dao suglasnost da se radi namirenja ovrhovoditeljeve tražbine može provesti ovrha na njoj, a potom stekao novu nekretninu, te bi u tom slučaju - i onda kada ne bi dao suglasnost - vrijedila ona prvotno dana suglasnost. Čini se da bi intenciji odredbe nov. čl. 75. st. 5. reč. 3. OZ-a 12 odgovaralo shvaćanje prema kojemu su njome pokrivene obje situacije. U protivnom, otvorila bi se vrata različitim manipulacijama ovršenika.

Odredba nov. čl. 75. st. 5. OZ-a 12 i nije najsretnije nomotehnički redigirana. Uz to, zakonodavac nije propisao odnos suglasnosti koju ovršenik daje u trenutku sklapanja pravnog posla kojim preuzima obvezu, a kojom izjavljuje da je suglasan da se radi namirenja ovrhovoditeljeve tražbine ovrha može provesti na njegovoj jedinoj nekretnini (nov. čl. 75. st. 5. reč. 1. OZ-a) te odredaba čl. 77. OZ-a 12 o zaštiti ovrhovoditelja, niti je intervenirao u odredbe čl. 77. OZ-a 12. Prema čl. 77. st. 1. OZ-a 12, ako je ovrhovoditelj na temelju pravnoga posla s ovršenikom stekao na nekoj stvari ili pravu založno ili slično pravo radi osiguranja tražbine čije prisilno ostvarenje na tom predmetu traži, ovršenik se ne može protiviti takvoj ovrsi pozivajući se na to da je riječ o stvari (nekretnini) nužnoj za zadovoljenje osnovnih životnih potreba (te na druge odredbe OZ-a 12 o izuzimanju od ovrhe ili o ograničenju ovrhe). Upitno je, naime, je li zakonodavac u odredbi nov. čl. 75. st. 5. reč. 1. OZ-a 12 aludirao na suglasnost za upis založnog prava na nekretnini (čl. 77. st. 1. OZ-a 12), a što je posebice važno ako se uzmu u obzir odredbe o posebnim uvjetima za određivanje ovrhe na nekretnini (nov. čl. 80.b OZ-a 12). ${ }^{100} \mathrm{U}$ prilog tomu da bi bila

97 Prema prijelaznim i završnim odredbama ZIDOZ-a 17, odredbe nov. čl. 75. st. 5. OZ-a 12 primjenjuje se na pravne poslove koji nastanu nakon stupanja na snagu tog Zakona (čl. 44. st. 3. ZIDOZ-a 17).

98 Kao i prije ZIDOZ-a 17, nekretnine za obavljanje poslovne djelatnosti ne smatraju se stvarima koje su nužne za obavljanje samostalne djelatnosti koja je ovršenikov glavni izvor sredstava za život, osim ako zakonom nije drugačije određeno (nov. čl. 75. st. 8. OZ-a 12).

99 O ovjeri potpisa (legalizaciji) v. čl. 77. Zakona o javnom bilježništvu iz 1993. godine, Narodne novine Republike Hrvatske, broj 78/1993, s kasnijim izmjenama i dopunama: Narodne novine Republike Hrvatske, broj 29/1994, 162/1998, 16/2007, 75/2009, 120/2016.

100 O posebnim uvjetima za određivanje ovrhe na nekretnini prema OZ-u 12 nakon ZIDOZ-a 17 v. infra ad 4.3. 
riječ o različitim suglasnostima govorile bi prijelazne i završne odredbe ZIDOZ-a 17, a prema kojima se odredbe nov. čl. 75. st. 5. OZ-a 12 o davanju suglasnosti da se ovrha može provesti i na jedinoj nekretnini nužnoj za zadovoljenje osnovnih životnih potreba primjenjuju na pravne poslove koji nastanu nakon stupanja na snagu tog Zakona (čl. 44. st. 3. ZIDOZ-a 17). Međutim, time i dalje nije riješeno pitanje primjenjuju li se odredbe o posebnim uvjetima za određivanje ovrhe na nekretnini samo na one nekretnine na kojima se zabilježbom ovrhe stječe pravo na namirenje ili i na one nekretnine na kojima je već upisana (dobrovoljna) hipoteka.

Iako bi se iz citirane odredbe nov. čl. 75. st. 5. reč. 1. OZ-a 12 moglo zaključiti da će takva jedina nekretnina biti (a priori, zakonom) izuzeta od ovrhe, osim u slučaju davanja suglasnosti da se radi namirenja ovrhovoditeljeve tražbine ovrha može provesti na njegovoj jedinoj nekretnini, to ipak nije slučaj. ZIDOZ-om 17 propisani su različiti kriteriji za ugovorne te izvanugovorne odnose odnosno tražbine koje proizlaze iz tih odnosa, a koje se ostvaruju u ovršnom postupku. Kod prisilnog ostvarenja tražbina iz ugovornih odnosa, sud će prijedlog za ovrhu na nekretnini (pa i onoj u odnosu na koju je ovršenik izjavio da je suglasan da je riječ namirenja ovrhovoditeljeve tražbine provede ovrha na njegovoj jedinoj nekretnini) odbiti ako glavnica tražbine radi čijeg se namirenja ovrha traži ne prelazi iznos od 20.000,00 kuna (nov. čl. 80.b st. 1. OZ-a 12) (tzv. vrijednosni kriterij). Ako iznos glavnice tražbine radi čijeg se namirenja ovrha traži prelazi iznos od 20.000,00 kuna, primjenjuje se kod ostvarenja tražbina iz ugovornih odnosa test razmjernosti ("pravične ravnoteže") (nov. čl. 80.b st. 2. i 3. OZ-a 12; v. infra ad 4.3.). U slučaju prisilnog ostvarenja tražbina iz izvanugovornih odnosa primjenjuje se uvijek test razmjernosti (nov. čl. 75. st. 6. OZ-a 12; v. infra ad 4.3.). Stoga, neovisno o odredbi nov. čl. 75. st. 5. OZ-a 12 o zaštiti jedine nekretnine ovršenika koja je nužna za zadovoljenje osnovnih životnih potreba ovršenika, sud će kada to "pravičnost zahtijeva", odrediti i provesti ovrhu na nekretnini za stanovanje ako glavnica tražbine prelazi iznos od 20.000,00 kuna (arg. ex: nov. čl. 80.b st. 2. i 3. OZ-a 12) ili ako ovršenikova obveza (neovisno o njezinoj visini) potječe iz izvanugovornog obveznog odnosa (nov. čl. 75. st. 6. OZ-a 12).

Prema nov. čl. 75. st. 7. OZ-a 12, uz prijedlog za ovrhu na nekretnini protiv osobe koja je dala suglasnost da se radi namirenja ovrhovoditeljeve tražbine ovrha može provesti na njezinoj jedinoj nekretnini ovrhovoditelj je dužan podnijeti tu suglasnost, odnosno pravomoćnu presudu, javnu ili privatnu ispravu koja ima značenje javne isprave kojom dokazuje da ovršenik ili osoba koju je po zakonu dužan uzdržavati ima drugu nekretninu za stanovanje.

\subsection{POSEBNI UVJETI ZA ODREĐIVANJE OVRHE NA NEKRETNINI}

Prema OZ-u 12 nakon ZIDOZ-a 17, sud će prijedlog za ovrhu na nekretnini odbiti ako glavnica tražbine radi čijeg se namirenja ovrha traži ne prelazi iznos od 20.000,00 kuna, osim ako je prijedlog podnesen u vezi s prisilnim ostvarenjem tražbine radi zakonskoga uzdržavanja ili tražbine koja se odnosi na naknadu štete uzrokovane kaznenim djelom (nov. čl. 80.b st. 1. OZ-a 12).

Prvo, treba primijetiti da se navedena odredba nov. čl. 80.b st. 1. OZ-a 12 primjenjuje na sve slučajeve određivanje ovrhe na nekretnini, neovisno o tome je li nekretnina jedina i nužna za stanovanje ovršenika i osoba koje je po zakonu dužan uzdržavati te neovisno o tome je li ovršenik u trenutku sklapanja pravnog posla kojim preuzima obvezu izjavio da je suglasan 
da se radi namirenja ovrhovoditeljeve tražbine ovrha može provesti na njegovoj jedinoj nekretnini (arg. ex nov. čl. 80.b OZ-a 12). ${ }^{101},{ }^{102}$ To je posebice vidljivo kod prisilnog ostvarenja tražbina koje prelaze iznos od 20.000,00 kuna, a kod kojih je OZ-om 12 nakon ZIDOZ-a 17 izrijekom propisano da sud može odbiti prijedlog za ovrhu na nekretnini ako ocijeni da bi prodaja nekretnine narušila pravičnu ravnotežu između interesa ovršenika i interesa ovrhovoditelja (nov. čl. 80.b st. 2. OZ-a 12). Pritom bi sud morao uzeti u obzir, među ostalim, služi li nekretnina za stanovanje i zadovoljavanje osnovnih životnih potreba ovršenika i ima li ovršenik drugih nekretnina ili drugih mogućnosti da svoje potrebe zadovolji, kao i je li se ovršenik izjavom sadržanom u javnoj ispravi ili ovjerovljenoj privatnoj ispravi izričito suglasio s time da ovrhovoditelj radi namirenja određene tražbine zatraži namirenje prodajom određene nekretnine (nov. čl. 80.b. st. 3. OZ-a 12). Dakle, sud će primjenom vrijednosnog kriterija uvijek odbiti prijedlog za ovrhu na nekretnini ako glavnica tražbine koja potječe iz ugovornog odnosa, a radi čijeg se namirenja ovrha traži, ne prelazi iznos od 20.000,00 kuna.

Drugo, ako bi bila riječ o prisilnom ostvarenju tražbina koje potječu iz izvanugovornih odnosa, i to tražbine radi zakonskoga uzdržavanja ili tražbine radi naknade štete uzrokovane kaznenim djelom, trebao bi se primjenjivati uvijek test razmjernosti ("pravične ravnoteže") (nov. čl. 80.b st. 1. OZ-a 12): sud će, kad to pravičnost zahtijeva, odrediti i provesti ovrhu na nekretnini ako ovršenikova obveza potječe iz izvanugovornog obveznog odnosa (nov. čl. 75. st. 6. OZ-a 12). Pritom treba primijetiti da je krug tražbina koje potječu iz izvanugovornog odnosa u nov. čl. 80.b st. 1. OZ-a 12 drukčije propisan u odnosu na određivanje tzv. privilegiranih tražbina u OZ-u 12; dakle posrijedi bi trebale biti tražbine zakonskog uzdržavanja, posebice uzdržavanja djece, naknade štete nastale zbog narušenja zdravlja ili smanjenja, odnosno gubitka radne sposobnosti i naknade štete za izgubljeno uzdržavanje zbog smrti davatelja uzdržavanja (arg. ex čl. 172. st. 1. t. 1. OZ-a 12).

Ako glavnica tražbine radi čijeg se namirenja ovrha traži prelazi iznos od 20.000,00 kuna, sud može odbiti prijedlog za ovrhu na nekretnini ako ocijeni da bi prodaja nekretnine narušila "pravičnu ravnotežu" između interesa ovršenika i interesa ovrhovoditelja (nov. čl. 80.b st. 2. OZ-a 12). OZ-om 12 nije primjerice ni određeno kada bi to bila narušena pravična ravnoteža između interesa ovršenika i interesa ovrhovoditelja. Međutim, propisane su okolnosti koje bi sud morao uzeti u obzir pri ocjeni je li ta ravnoteža narušena. Pri ocjeni je li narušena pravična ravnoteža sud će uzeti u obzir okolnosti slučaja, a osobito: (1) je li vrijednost tražbine koja se namiruje nerazmjerno manja od vrijednosti nekretnine na kojoj se predlaže provesti ovrhu; (2) je li ovrhovoditelj učinio vjerojatnim da je ovrha na drugim predmetima ovrhe bila neuspješna, odnosno da nema drugih prikladnih mogućnosti da se tražbina u cijelosti ili u pretežnom dijelu namiri; (3) služi li nekretnina za stanovanje i zadovoljavanje osnovnih životnih potreba ovršenika te ima li ovršenik drugih nekretnina ili drugih mogućnosti da svoje potrebe zadovolji; (4) ima li ovrhovoditelj osobito opravdan interes za hitnim namirenjem tražbine radi ostvarenja vlastitoga uzdržavanja ili drugih važnih razloga; (5) je li se ovršenik izjavom sadržanom u javnoj ispravi ili ovjerovljenoj privatnoj ispravi izričito suglasio s time da ovrho-

101 Vidjeti Mišljenje i amandmani Vlade uz Konačni prijedlog Zakona o izmjenama i dopunama Ovršnog zakona, Zagreb, srpanj 2017., URL=http://www.sabor.hr/konacni-prijedlog-zakona-o-izmjenama-i-dopunam0035, str. 5. Pristupljeno 19. srpnja 2017.

102 Različito od odredbe nov. čl. 75. st. 5. OZ-a 12, citirana odredba nov. čl. 80.b st. 1. OZ-a 12 primjenjivala bi se i na ovrhu na nekretnini ovršenika - fizičke osobe koja obavlja registriranu djelatnost (arg. ex nov. čl. 80.b OZ-a 12). 
voditelj radi namirenja određene tražbine zatraži namirenje prodajom određene nekretnine (nov. čl. 80.b. st. 3. OZ-a 12).

Iako u prijelaznim i završnim odredbama ZIDOZ-a 17 nije iskorištena mogućnost da se propiše da se odredbe o posebnim uvjetima određivanje ovrhe na nekretnini (čl. 15. ZIDOZ-a 17) primjenjuju i na postupke u tijeku (naravno, ako je to još moguće), trebalo bi uzeti da je kriterij "pravične ravnoteže" između interesa ovršenika i interesa ovrhovoditelja te dužna pažnja suda pri određivanju predmeta ovrhe sadržana i u čl. 6. OZ-a 12 o zaštiti dostojanstva ovršenika. U prilog tomu govorio bi i predmet Vaskrsić protiv Slovenije.

\subsection{STAMBENO ZBRINJAVANJE OVRŠENIKA}

Umjesto prava ovršenika da kao najmoprimac nastavi koristiti prodanu nekretninu, ZIDOZ-om 17 odredbama triju članaka propisano je stambeno zbrinjavanje ovršenika. Treba pritom primijetiti da se odredbe prij. čl. 127. st. 2. - 5. OZ-a 12 o pravu ovršenika na korištenje prodane nekretnine kao najmoprimac primjenjuju i nakon donošenja ZIDOZ-a 17 na one postupke koji su pokrenuti prije stupanja na snagu ZIDOZ-a 17 (čl. 44. st. 1., čl. 47. ZIDOZ-a 17), naravno, ako je još moguće podnijeti prijedlog u postupku (arg. ex prij. čl. 127. st. 3. OZ 12). Također, odredbe o stambenom zbrinjavanju ovršenika (čl. 20. ZIDOZ-a 17) primjenjuju se na sve postupke koji su u tijeku neovisno o tome prema kojem su zakonu pokrenuti (čl. 44. st. 2. ZIDOZ-a 17); dakle, i na postupke koji su pokrenuti prema OZ-u 12 prije stupanja na snagu ZIDOZ-a 17.

Ovršenik koji se radi naplate novčane tražbine dužan iseliti iz nekretnine prodane u ovršnom postupku ima pravo na novčanu naknadu za troškove stambenog zbrinjavanja iz sredstava državnog proračuna, ako (1) je u nekretnini iz koje se dužan iseliti stanovao prije pokretanja ovršnog postupka; (2) je dobrovoljno predao nekretninu kupcu; te (3) nema u vlasništvu drugu nekretninu za zadovoljenje osnovnih stambenih potreba (nov. čl. 131.a st. 1. OZ-a 12). ${ }^{103}$

Postupak za priznavanje prava na novčanu naknadu za troškove stambenog zbrinjavanja pokreće se na zahtjev ovršenika nadležnom centru za socijalnu skrb u roku od 30 dana od dana predaje nekretnine kupcu. Uz zahtjev ovršenik je dužan priložiti rješenje o ovrsi kojim je određena ovrha na nekretnini te dokaz o sklopljenom ugovoru o najmu nekretnine za stambeno zbrinjavanje (nov. čl. 131.a st. 2. OZ-a 12). O priznavanju prava na novčanu naknadu za troškove stambenog zbrinjavanja odlučuje centar za socijalnu skrb (nov. čl. 131.a st. 3. OZ-a 12). O podnošenju zahtjeva za priznavanje prava na novčanu naknadu za troškove stambenog zbrinjavanja centar za socijalnu skrb dužan je bez odgode obavijestiti sud koji je donio rješenje o ovrsi. Sud će zaključak o predaji nekretnine kupcu dostaviti centru za socijalnu skrb koji mu je dostavio obavijest (nov. čl. 131.a st. 4. OZ-a 12).

Iako je u odredbi nov. čl. 131.a st. 2. reč. 1. OZ-a 12 propisano da se postupak za priznavanje prava na novčanu naknadu za troškove stambenog zbrinjavanja pokreće na zahtjev ovrše-

103 Uzimajući u obzir da je jedna od pretpostavaka stjecanja prava na novčanu naknadu dobrovoljna predaja nekretnine kupcu, može se pretpostaviti da neće biti mnogo zahtjeva te ostvarivanja prava na novčanu naknadu za troškove stambenog zbrinjavanja prema odredbi nov. čl. 131.a st. 1. OZ-a 12. Naime, u praksi su u pravilu češće situacije u kojima ovršenici ne žele dobrovoljno predati nekretninu u kojoj su stanovali ("dom"). Neovisno o tome, ovršenik će moći ostvariti pravo na socijalnu uslugu privremenog smještaja u kriznim situacijama (v. nov. čl. 131.c OZ-a 12). 
nika u roku od 30 dana od dana predaje nekretnine kupcu (uz prilaganje dokaza o sklopljenom ugovoru o najmu nekretnine za stambeno zbrinjavanje), u odredbi nov. čl. 131.a st. 5. OZ-a 12 propisana je mogućnost da ovršenik zahtjev za priznavanje prava na novčanu naknadu za troškove stambenog zbrinjavanja podnese nakon što je sud donio rješenje o dosudi nekretnine, a prije pravomoćnosti rješenja o dosudi nekretnine i prije nego što je kupac položio kupovninu. Stoga je nejasno, naime, može li se taj postupak pokrenuti i prije nego što je ovršenik predao nekretninu kupcu i sklopio ugovor o najmu nekretnine za svoje stambeno zbrinjavanje. Odredbama nov. čl. 131.a st. 5. OZ-a 12 propisano je samo da će sud u tom slučaju (podnošenja zahtjeva centru za socijalnu skrb za priznavanje prava na naknadu za troškove stambenog zbrinjavanja prije pravomoćnosti rješenja o dosudi nekretnine i prije nego što je kupac položio kupovninu) zaključak o predaji nekretnine kupcu donijeti nakon što protekne rok od 30 dana od dana kada se ispune uvjeti za donošenje zaključka o predaji nekretnine kupcu.

Čini se da je odredbama nov. čl. 131.a st. 5. OZ-a 12 otvorena mogućnost pokretanja postupka za priznavanje prava na novčanu naknadu za troškove stambenog zbrinjavanja nakon donošenja rješenja o dosudi, i prije predaje nekretnine kupcu, a čime si ovršenik osigurava mogućnost ostanka u prodanoj nekretnini dodatnih 30 dana, uzimajući u obzir da će sud u tom slučaju donijeti zaključak o predaji nekretnine kupcu nakon što protekne rok od 30 dana od dana kada se ispune uvjeti za donošenje zaključka o predaji nekretnine kupcu.

Pravo na novčanu naknadu za troškove stambenog zbrinjavanja priznaje se od dana predaje nekretnine kupcu, isplaćuje se mjesečno, a priznaje se najduže do 18 mjeseci (nov. čl. 131.a st. 6. OZ-a 12). Visina novčane naknade za troškove stambenog zbrinjavanja iznosi mjesečno najviše do 500\% osnovice na temelju koje se izračunava iznos drugih prava prema propisima u socijalnoj skrbi, a priznaje se u visini ugovorene najamnine (nov. čl. 131.a st. 7. OZ-a 12). O žalbi protiv rješenja centra za socijalnu skrb kojim se odlučuje o pravu na novčanu naknadu za troškove stambenog zbrinjavanja odlučuje ministarstvo nadležno za poslove socijalne skrbi (nov. čl. 131.a st. 8. OZ-a 12). Žalba ne odgađa izvršenje rješenja (nov. čl. 131.a st. 9. OZ-a 12).

Prema nov. čl. 131.b st. 1. OZ-a 12, korisnik kojem je priznato pravo na novčanu naknadu za troškove stambenog zbrinjavanja dužan je centru za socijalnu skrb prijaviti svaku promjenu koja utječe na daljnje ostvarivanje ili na visinu novčane naknade odmah, a najkasnije u roku od osam dana od dana nastanka promjene. Ako korisnik nakon promijenjenih okolnosti i dalje ispunjava uvjete za priznavanje prava na novčanu naknadu za troškove stambenog zbrinjavanja u manjem ili većem iznosu od već priznatog prava, pravo u izmijenjenom iznosu priznaje se danom nastanka promijenjenih okolnosti (nov. čl. 131.b st. 2. OZ-a 12). Ako zbog promijenjenih okolnosti korisnik ne ispunjava uvjete za daljnje korištenje prava na novčanu naknadu za troškove stambenog zbrinjavanja, pravo prestaje danom nastanka promijenjenih okolnosti (nov. čl. 131.b st. 3. OZ-a 12).

Osim citiranih odredaba o visini naknade za troškove stambenog zbrinjavanja, pravu na žalbu te odlukama u slučaju promijenjenih okolnosti, OZ 12 ne sadrži (daljnja) (materijalno i postupovnopravna) pravila, niti upućuje na primjenu propisa kojim se uređuje djelatnost socijalne skrbi. ${ }^{104}$ Ostaje nejasno, stoga, prema kojim pravilima će se, primjerice, odrediti (mjesna)

104 Naknadu za troškove stanovanja, među ostalim, najamninu propisuje i Zakon o socijalnoj skrbi (Narodne novine Republike Hrvatske, broj 157/2013, 152/2014, 99/2015, 52/2016, 16/2017; u daljnjem tekstu: ZSS). Pravo na naknadu troškova stanovanja priznaje se korisniku zajamčene minimalne naknade (v. čl. 41. ZSS-a). 
nadležnost centra za socijalnu skrb, postupovna pravila prema kojima centar za socijalnu skrb postupa, pitanja naknade štete ako korisnik ostvari pravo na temelju neistinitih ili netočnih podataka ili ne prijavi promjenu koja utječe na gubitak ili opseg prava i sl.

Prema OZ-u 12 nakon ZIDOZ-a 17, iznimno, ako ovršenik i osoba koju je ovršenik po zakonu dužan uzdržavati, a koja je u nekretnini iz koje se ovršenik dužan iseliti stanovala prije pokretanja ovršnog postupka, ne može potrebe stambenog zbrinjavanja zadovoljiti priznavanjem prava na novčanu naknadu za troškove stambenog zbrinjavanja iz sredstava državnog proračuna (nov. čl. 131.a st. 1. OZ-a 12), može ostvariti pravo na socijalnu uslugu privremenog smještaja u kriznim situacijama (nov. čl. 131.c OZ-a 12). Iz citirane odredbe nov. čl. 131.c OZ-a 12 proizlazi, dakle, da i oni ovršenici koji dobrovoljno ne predaju nekretninu ili koji pak u roku od 30 dana od predaje nekretnine ne podnesu zahtjev centru za socijalnu skrb, imaju pravo na socijalnu uslugu privremenog smještaja u kriznim situacijama. Treba, međutim, primijetiti da OZ 12 ne propisuje rok trajanja toga prava, posebnosti postupka u kojem se o njemu odlučuje (stvarna i mjesna nadležnost tijela, pravozaštitni put za ostvarenje toga prava, postupovna pravila, i sl.) niti upućuje na odgovarajuću primjenu propisa kojima se uređuje djelatnost socijalne skrbi. ${ }^{105}$

\section{UMJESTO ZAKLJUČKA: EVALUACIJA IZMJENA I DOPUNA OVRŠNOG ZAKONA IZ SRPNJA 2017. GODINE}

Iz sumarne povijesne geneze uređenja ovrhe na nekretnini u kontekstu zaštite ovršenika i jedine nekretnine za stanovanje te analize posljednjih izmjena i dopuna OZ-a 12 iz 2014. i 2017. godine, vidljivo je da su izmjene i dopune ovršnopravnog sustava rađene prema načelu "pokušaja i pogrešaka", a u konačnici vratilo se na temelje izvornog uređenja Zakona iz 1996. godine. Tako je u utvrđivanju vrijednosti nekretnine prema izvornom uređenju OZ-a 96 sudjelovao vještak, a što je (ponovno) propisano OZ-om 12 nakon ZIDOZ-a 14. I najniža prodajna cijena prema kojoj se nekretnina može prodati na prvom dražbenom ročištu vraćena je ZIDOZ-om 14 na vrijednost iz izvornog uređenja OZ-a 96. Dok je OZ 96 u izvornom uređenju propisivao promjenu predmeta ovrhe u slučaju kad je bila predložena ovrha na nekretnini, pod sličnim pretpostavkama ZIDOZ-om 14 bila su unesena pravila u OZ 12 o odgodi ovrhe na prijedlog ovršenika, da bi nakon ZIDOZ-a 17 imali nimalo jednostavna pravila koja zapravo propisuju izuzimanje od ovrhe nekretnine (i to ne samo jedine nekretnine koja služi za zadovoljenje osnovnih životnih potreba ovršenika) kombinacijom kauzalno-vrijednosnog kriterija te kriterija pravične ravnoteže. Na ovo potonje zasigurno je utjecala, osim gospodarsko-socijalne situacije, i praksa Europskog suda za ljudska prava. Uz to, i pravo na "nužni smještaj” odnosno "stambeno zbrinjavanje" nije novost OZ-a 12 nakon ZIDOZ-a 17, ono je već bilo propisano u izvornom uređenju OZ-a 96. Međutim, dok je OZ 96 u svojoj izvornoj varijanti uređenje toga prava prepuštao posebnom propisu (koji nije bio donesen), ZIDOZ-om 17 pokušalo se na neuspješan način integrirati socijalna prava i usluge u ovršnopravni sustav. 
Sumarno, zaštita prava ovršenika u ovrsi na nekretnini, nakon ZIDOZ-a 17, nastoji se ostvariti propisivanjem jedine nekretnine u kojoj ovršenik i osobe koje je po zakonu dužan uzdržavati stanuju kao nekretnine nužne za zadovoljenje osnovnih životnih potreba ovršenika (arg. ex nov. čl. 75. st. 5. OZ-a 12). Iako bi se iz te odredbe OZ-a 12 moglo zaključiti da će takva jedina nekretnina biti (a priori, zakonom) izuzeta od ovrhe, osim u slučaju davanja suglasnosti ovršenika pri sklapanju pravnog posla kojim preuzima obvezu, to ipak nije slučaj. ZIDOZ-om 17 propisani su različiti kriteriji za ugovorne te izvanugovorne odnose odnosno tražbine koje proizlaze iz tih odnosa, a koje se ostvaruju u ovršnom postupku. Kod prisilnog ostvarenja tražbina iz ugovornih odnosa, sud će prijedlog za ovrhu na nekretnini (pa i onoj u odnosu na koju je ovršenik izjavio da je suglasan da se radi namirenja ovrhovoditeljeve tražbine provede ovrha na njegovoj jedinoj nekretnini) odbiti ako glavnica tražbine radi čijeg se namirenja ovrha traži ne prelazi iznos od 20.000,00 kuna (nov. čl. 80.b st. 1. OZ-a 12) (tzv. vrijednosni kriterij). U ostalim slučajevima ugovornih obveza, ako iznos glavnice tražbine prelazi iznos od 20.000,00 kuna primjenjuje se test razmjernosti (odnosno kako OZ 12 propisuje, "pravične ravnoteže") (nov. čl. 80.b st. 2. i 3. OZ-a 12). U slučaju prisilnog ostvarenja tražbina iz izvanugovornih odnosa primjenjuje se uvijek test razmjernosti (nov. čl. 75. st. 6. OZ-a 12).

Stoga, neovisno o odredbi nov. čl. 75. st. 5. OZ-a 12 o zaštiti jedine nekretnine ovršenika koja je nužna za zadovoljenje osnovnih životnih potreba, sud će kada to "pravičnost zahtijeva", odrediti i provesti ovrhu na nekretnini za stanovanje ako glavnica tražbine radi čijeg se namirenja ovrha traži prelazi iznos od 20.000,00 kuna (arg. ex: nov. čl. 80.b st. 2. i 3. OZ-a 12) ili ako ovršenikova obveza (neovisno o njezinoj visini) potječe iz izvanugovornog obveznog odnosa (nov. čl. 75. st. 6. OZ-a 12).

Primjena novih pravila OZ-a 12 nakon ZIDOZ-a 17, otvara određena načelno teorijska ali i implementacijsko-praktična pitanja:

(1) zakonodavac nije propisao odnos suglasnosti koju ovršenik daje u trenutku sklapanja pravnog posla kojim preuzima obvezu, a kojom izjavljuje da je suglasan da se radi namirenja ovrhovoditeljeve tražbine ovrha može provesti na njegovoj jedinoj nekretnini (nov. čl. 75. st. 5. reč. 1. OZ-a) te odredaba čl. 77. OZ-a 12 o zaštiti ovrhovoditelja, niti je intervenirao u odredbe čl. 77. OZ-a 12. Upitno je stoga je li zakonodavac u odredbi nov. čl. 75. st. 5. reč. 1. OZ-a 12 aludirao na suglasnost za upis založnog prava na nekretnini (čl. 77. st. 1. OZ-a 12), a što je posebice važno ako se uzmu u obzir odredbe o posebnim uvjetima za određivanje ovrhe na nekretnini (nov. čl. 80.b OZ-a 12). Dakle, ostaje nejasno primjenjuju li se odredbe o posebnim uvjetima za određivanje ovrhe na nekretnini samo na one nekretnine na kojima se zabilježbom ovrhe stječe pravo na namirenje ili i na one nekretnine na kojima je već upisana (dobrovoljna) hipoteka. Iz intencije odredaba nov. čl. 80.b OZ-a 12, posebice njegova stavka 3., ali i obrazloženja uz čl. 15. ZIDOZ-a 17, ${ }^{106}$ čini se, da bi se na sve nekretnine - tako i one na kojima postoji (dobrovoljna) hipoteka - primjenjivale odredbe o posebnim uvjetima za odredivanje ovrhe; dakle, ovrha na nekretnini bi se određivala ovisno o vrijednosnom kriteriju tražbine koja se prisilno ostvaruje, kombiniranom s testom razmjernosti (nov. čl. 80.b OZ-a 12). Radi pravne sigurnosti te zaštite ovrhovoditelja, stoga, bilo je potrebno izrijekom urediti pitanje odnosa ovrhe na nekretnini na kojoj je već upisana (dobrovoljna) hipoteka radi nami-

106 Obrazloženje uz amandman IV. u: Mišljenje i amandmani Vlade uz Konačni prijedlog Zakona o izmjenama i dopunama Ovršnog zakona, op. cit. u bilj. 101, str. 5. 
renja tražbine koja je njome osigurana te odredaba o posebnim uvjetima za određivanje ovrhe na nekretnini; ${ }^{107}$

(2) kod prisilnog ostvarenja tražbina iz ugovornih odnosa zakonodavac se opredijelio, primarno, za vrijednosni kriterij, kombinirajući ga s testom razmjernosti kod tražbina koje prelaze određeni iznos. Upitno je kako je zakonodavac i zašto odredio iznos od 20.000,00 kuna kao iznos vrijednosti tražbine ispod kojega se ne može provesti ovrha na (niti jednoj) nekretnini. Zakon o parničnom postupku, ${ }^{108}$ npr., uređujući postupak u sporovima male vrijednosti, propisuje kao takve sporove do 10.000,00 kuna (čl. 458. ZPP), a u postupku pred trgovačkim sudovima sporove do 50.000,00 kuna (čl. 502. st. 1. ZPP). OZ 12 prije ZIDOZ-a 17 propisivao je pak nesuspenzivnost žalbe protiv odluka kojom se fizičkoj osobi koja nije obavljala registriranu djelatnost nalagalo isplata tražbine, a kao iznos tražbine za koje je to pravilo vrijedilo bio je utvrdio iznos do 5.000,00 kuna, dok za fizičke osobe koje su obavljale registriranu djelatnost iznos do 10.000,00 kuna (prij. čl. 26. st. 1. OZ 12). ${ }^{109}$ Da je primjena vrijednosnog kriterija dvojbena možda još više ukazuje proces koji je prethodio donošenju ZIDOZ-a $17 .{ }^{110}$ Osim toga, isključenje mogućnosti namirenja određenih tražbina iz vrijednosti nekretnine primjenom vrijednosnog kriterija može se smatrati i diskriminatornim u odnosu na tražbine drugih ovrhovoditelja čiji iznos prelazi 20.000,00 kuna. Konačno, zašto je zakonodavac a priori, zakonom isključio mogućnost ovrhe na nekretnini ako tražbina iz ugovornog odnosa ne prelazi 20.000,00 kuna? Ne bi li bilo pravednije, uvažavajući pravičnu ravnotežu interesa ovršenika i ovrhovoditelja, da je to propustio ocjeni suda kao što je to učinio kod tražbina koje prelaze iznos od 20.000,00 kuna. Iz odluke Europskog suda za ljudska prava u predmetu Vaskrsić v. Slovenija proizlazi, naime, upravo primjena testa razmjernosti između mjere koja se primjenjuje te cilja koji se nastoji postići, odnosno sud mora cijeniti da li mjerama državne intervencije odnosna osoba mora trpjeti neproporcionalan te pretjeran teret. ${ }^{111}$ Stoga, bilo je potrebno prepustiti ocjeni suda (ne)razmjer tražbine ovrhovoditelja te vrijednosti nekretnine ovršenika, a ne a priori isključivati ovrhu na nekretnini tretirajući određene tražbine kao manje značajne;

(3) kod ostvarivanja tražbina iz izvanugovornih odnosa zakonodavac se opredijelio samo za primjenu testa razmjernosti. Ono što, međutim, može biti dvojbeno jest određenje takvih tražbina. OZ 12 propisuje, naime, tražbine radi zakonskoga uzdržavanja ili tražbine radi naknade štete uzrokovane kaznenim djelom (nov. čl. 80.b st. 1. OZ-a 12) kao tražbine na koje bi se primjenjivao uvijek test "pravične ravnoteže" (nov. čl. 75. st. 6. OZ-a 12). S druge strane, OZ

107 U tom kontekstu mogla bi biti značajna presuda u predmetu Vrzić protiv Hrvatske od 12. srpnja 2016., dostupno na: URL=https:// uredzastupnika.gov.hr/UserDocsImages//dokumenti/Presude\%20i\%20odluke//Vrzi\% C4\%87\%20protiv\%20Hrvatske,\%20presuda. pdf. Pristupljeno 19. srpnja 2017. U tom predmetu Europski sud za ljudska prava utvrdio je da nije bilo povrijeđeno pravo na dom iz čl. 8. EK-a jer "prodaja kuće podnositelja zahtjeva u ovršnom postupku bila je posljedica neispunjavanja ugovornih obveza podnositelja zahtjeva. Štoviše, bila je to posljedica na koju su podnositelji zahtjeva izričito pristali”. Europski sud za ljudska prava: presuda Vrzić protiv Hrvatske od 12. srpnja 2016., str. 12. U ovom predmetu riječ je bila o ovršnoj prodaji nekretnine na kojoj je postojalo založno pravo radi osiguranja tražbine ovrhovoditelja.

Zakon o parničnom postupku, Službeni list Socijalističke Federativne Republike Jugoslavije, broj 4/1977 - 35/1991; Narodne novine Republike Hrvatske, broj 26/1991, 53/1991, 91/1992, 112/1999, 88/2001 - v. čl. 50. Zakona o arbitraži, 117/2003, 88/2005 - v. čl. 129. Zakona o izmjenama i dopunama Ovršnog zakona, 2/2007 - v. Odluku USRH od 20. prosinca 2006. , 84/2008, 96/2008 - v. Odluku USRH od 9. srpnja 2008., 123/2008 - ispravak, 57/2011, 148/2011 - pročišćeni tekst, 25/2013, 89/2014 - v. Odluku USRH od 11. srpnja 2014. (u daljnjem tekstu: ZPP).

109 Citirana je odredba brisana čl. 4. ZIDOZ-a 17.

110 Vidjeti tako Amandmane na Konačni prijedlog Zakona o izmjenama i dopunama Ovršnog zakona iz travnja 2017. na: URL=http:// www.sabor.hr/konacni-prijedlog-zakona-o-izmjenama-i-dopunam0035. Pristupljeno 18. srpnja 2017.

111 Presuda Vaskrsić protiv Slovenije, op. cit. u bilj. 12, str. 18. 
12 na drugim mjestima privilegira širi krug tražbina, i to tražbine zakonskoga uzdržavanja, posebice uzdržavanja djece, naknade štete nastale zbog narušenja zdravlja ili smanjenja, odnosno gubitka radne sposobnosti i naknade štete za izgubljeno uzdržavanje zbog smrti davatelja uzdržavanja (arg. ex: čl. 172. st. 1.t. 1., čl. 173. st. 1. i 2. OZ-a 12). Stoga bi, arg. a cohaerentia, a completudine ex čl. 172. st. 1. t. 1. te čl. 173. st. 1. i 2. OZ-a 12, trebalo odrediti tražbine zakonskoga uzdržavanja, posebice uzdržavanja djece, naknade štete nastale zbog narušenja zdravlja ili smanjenja, odnosno gubitka radne sposobnosti i naknade štete za izgubljeno uzdržavanje zbog smrti davatelja uzdržavanja kao tražbine na koje bi se primjenjivao (samo) test razmjernosti u ovrsi na nekretnini; ${ }^{112}$

(4) OZ-om 12 nakon ZIDOZ-a 17 propisano je pravo ovršenika na stambeno zbrinjavanje, $\mathrm{i}$ to pravo na naknadu za troškove stambenog zbrinjavanja te pravo na privremeni smještaj u kriznim situacijama. Pravo na naknadu troškova stanovanja te pravo na privremeni smještaj u kriznim situacijama su prava odnosno socijalne usluge koje su uređene ZSS-om. U kontekstu toga, otvara se pitanje odnosa tih dvaju zakona: hoće li korištenje prava po jednom isključivati mogućnost korištenja prava po drugom zakonu. Osim toga, kao što je u radu već navedeno, OZ-om 12 nisu uređena (materijalnopravna te postupovnopravna) pitanja uz određivanje prava na naknadu za troškove stambenog zbrinjavanja te prava na privremeni smještaj u kriznim situacijama niti je upućeno na odgovarajuću primjenu ZSS-a. Stoga ostaje otvorenim pitanje prema kojim će pravilima centri za socijalnu skrb određivati navedena prava te kakav je njihov odnos prema sustavu socijalne skrbi, pravima te socijalnim uslugama. Konačno, propisivanjem stambenog zbrinjavanja ovršenika u OZ-u 12 dalje se komplicira i tako kompleksan sustav socijalne skrbi. Nije li bilo jednostavnije te primjerenije to prepustiti ZSS-u na način da se preispitaju pretpostavke pod kojima se inače mogu steći prava na naknadu troškova stanovanja te privremeni smještaj u kriznim situacijama?

(5) ZIDOZ-om 17 te pokušajem zaštite jedine nekretnine ovršenika nužne za zadovoljenje njegovih osnovnih životnih potreba intenziviralo se pitanje odnosa ovrhe te osobnog stečaja. ${ }^{113}$ ZSP sadrži odredbe o "zaštiti doma" potrošača nad kojim se provodi osobni stečaj. Tako potrošač može predložiti da se do okončanja razdoblja provjere ponašanja ${ }^{114}$ ne prodaje nekretnina koja mu je potrebna za stanovanje ako u vlasništvu nema drugu nekretninu te ako nema na raspolaganju drugi smještaj niti ga je u mogućnosti osigurati (čl. 64. st. 1. ZSP-a). ${ }^{115}$ Ovršni postupak bi, dakle, trebao biti pravozaštitni put u onim slučajevima kad je ovršenik

112 Npr., i Zakon o stečaju potrošača iz 2015. godine (Narodne novine Republike Hrvatske, broj 100/2015; u daljnjem tekstu: ZSP) određuje da se potrošač ne može osloboditi od sljedećih tražbina: (1) zakonskih obveza na uzdržavanje djece, roditelja i drugih osoba koje je po zakonu dužan uzdržavati; (2) vraćanja imovinske koristi ostvarene kaznenim djelom ili prekršajem; (3) naknade štete nastale kaznenim djelom ili prekršajem; te (4) naknade štete zbog smrti ili teže tjelesne ozljede (čl. 77. ZSP-a).

113 ZSP koristi izraz "stečaj" te "potrošač”. Postupak stečaja potrošača provodi se nad imovinom potrošača (čl. 4. st. 1. ZSP-a). Potrošačem se u smislu ZSP-a smatra svaka fizička osoba koja sklapa pravni posao ili djeluje na tržištu izvan svoje trgovačke, poslovne, obrtničke ili profesionalne djelatnosti (čl. 4. st. 2. ZSP-a), a što bi odgovaralo, dakle, (ovršnopravnom) pojmu fizičke osobe koja ne obavlja registriranu djelatnost. Osim toga, uz ispunjenje propisanih pretpostavaka, potrošačem se u smislu ZSP-a smatra i fizička osoba obveznik poreza na dohodak od samostalne djelatnosti prema odredbama Zakona o porezu na dohodak $\mathrm{i}$ fizička osoba obveznik poreza na dobit prema odredbama Zakona o porezu na dobit (čl. 4. st. 3. ZSP-a).

114 Rješenjem o zaključenju postupka stečaja potrošača sud će odrediti razdoblje provjere ponašanja koje ne može biti kraće od godinu dana ni dulje od pet godina (čl. 69. st. 1. ZSP-a).

115 Sud može odlučiti da se nekretnina ne prodaje do okončanja razdoblja provjere ponašanja nakon te će nakon tog razdoblja ocijeniti svrhovitost prodaje nekretnine, vodeći računa o opsegu namirenja svih vjerovnika koji će se namiriti iz prodajne cijene nekretnine (čl. 64. st. 3. reč. 2. ZSP-a). 
sposoban za plaćanje, ${ }^{116}$ kada ima imovinu iz koje bi se mogla namiriti tražbina ovrhovoditelja. Ako to ne bi bio slučaj, odnosno ako bi ovršenik imao samo jedinu nekretninu nužnu za zadovoljenje osnovnih životnih potreba, trebalo bi optirati za provođenje stečaja potrošača. I ne bi li bilo dosljednije te pravednije da se ostvarivanje zaštite jedine nekretnine nužne za zadovoljenje osnovnih životnih potreba prepustilo pravilima stečaja potrošača? Naravno, to bi podrazumijevalo i da je potrošač odnosno ovršenik pošten, da podnese zahtjev za provedbu izvansudskog postupka svakako prije donošenja rješenja o ovrsi na nekretnini, ${ }^{117}$ ali i veliku discipliniranost potrošača tijekom razdoblja provjere ponašanja; ${ }^{118}$

(6) zaključno, izmjene i dopune OZ-a 12 iz 2014., posebice iz 2017. godine, svjedoče promjeni pravozaštitne svrhe ovršnog postupka. Od prisilnog namirenja tražbine ovrhovoditelja, postupno se razvija koncept ovrhe, kako pod utjecajem prakse Europskog suda za ljudska prava tako i pod utjecajem gospodarsko-socijalnih prilika, u kojem rizik namirenja tražbine snosi i sam ovrhovoditelj. U tom novom konceptu zadatak bi ovršnog sustava, čini se, trebao biti ponajprije ispitivanje mogućnosti namirenja tražbine ovrhovoditelja. Ako bi ta mogućnost postojala, daljnji bi cilj bio uspostava dijaloga između ovršenika i ovrhovoditelja kako bi se izvidjeli mogući modaliteti namirenja tražbine ovrhovoditelja. ${ }^{119}$ Ako mogućnosti namirenja tražbine ovrhovoditelja iz imovine ovršenika ne bi postojala, rizik bi u konačnici (dijelom) snosio i ovrhovoditelj koji bi pro futuro trebao razmisliti s kojim osobama ulazi u pravne odnose. ${ }^{120}$

\section{LITERATURA}

1. Barbić, J. (ur.), Pravo na dom, Hrvatska akademija znanosti i umjetnosti, Zagreb, 2016.

2. Bugarin, B., Ovrha i pravo na dom, Hrvatska pravna revija, god. 16, br. 6, 2016., str. 14.-20.

3. Čuveljak, J., O ovrsi na nekretnini, Hrvatska pravna revija, br. 7-8, 2007., str. 105.-116.

4. Dika, M., Građansko ovršno pravo, I. knjiga, Opće građansko ovršno pravo, Narodne novine, Zagreb, 2007.

5. Dika, M., Novine u Ovršnom zakonu iz 2010. s posebnim osvrtom na ovrhu na novčanim tražbinama, Aktualnosti hrvatskog zakonodavstva i pravne prakse: građansko, trgovačko, radno i procesno pravo u praksi, Godišnjak 18, 2011., str. 285.-329.

6. Dika, M., O noveli Ovršnog zakona od 15. srpnja 2014., Pravo u gospodarstvu, vol. 54, br. 5, 2015. , str. 1129.-1202.

7. Dika, M., Ovrha na nekretnini, u: Barbarić, K. (ur.), Nekretnine u pravnom prometu - pravni i porezni aspekti, Inženjerski biro, Zagreb, prosinac 1998., str. 123.-169.

116 Postupak stečaja potrošača može se otvoriti samo ako je potrošač nesposoban za plaćanje (čl. 5. st. 1. ZSP-a). Smatrat će se da je potrošač nesposoban za plaćanje ako najmanje 90 dana uzastopno ne može ispuniti jednu ili više dospjelih novčanih obveza u ukupnom iznosu većem od 30.000,00 kuna (čl. 5. st. 3. ZSP-a).

117 Usp. Bugarin, B., op. cit. u bilj. 6, str. 18.

118 Vidjeti čl. 2. te čl. 75. ZSP-a.

119 Usp. Hess, B., Different Enforcement Structures, u: Van Rhee, C. H.; Uzelac, A. (ur.), Enforcement and Enforceability, Intersentia, Antwerp/Oxford/Portland, 2010., str. 53.

120 Prebacivanje rizika na ovrhovoditelja posebice je vidljivo u slučajevima kada je ovršenik dao izričitu suglasnost pri sklapanju pravnog posla kojim preuzima obvezu da ovrhovoditelj radi namirenja određene tražbine može zatraži namirenje prodajom jedine nekretnine (nov. čl. 75. st. 5. OZ-a 12). Naime, i u tim slučajevima primjenjuje se vrijednosni kriterij te test pravične ravnoteže u ovršnoj prodaji nekretnine (v. nov. čl. 80.b OZ-a 12). 
8. Hess, B., Different Enforcement Structures, u: Van Rhee, C. H.; Uzelac, A. (ur.), Enforcement and Enforceability, Intersentia, Antwerp/Oxford/Portland, 2010., str. 41.-61.

9. Hrastinski Jurčec, Lj., Ovrha na nekretninama, Javni bilježnik, god. 10, 2006., br. 23, str. 11.-30.

10. Jelinović, V., Ovrha na nekretninama od 1. 1. 2015., Financije, pravo i porezi, br. 3, 2015., str. 171.-179.

11. Kontrec, D., Pravo na dom u praksi Europskog suda i domaćih sudova, Aktualnosti hrvatskog zakonodavstva i pravne prakse: građansko, trgovačko, radno i procesno pravo u praksi, Godišnjak 23, 2016. str. 29.-65.

12. Maganić, A., Praksa Europskog suda za ljudska prava i pravo na dom, u: Barbić, J. (ur.), Pravo na dom, Hrvatska akademija znanosti i umjetnosti, Zagreb, 2016., str. 19.-53.

13. Marković, S., Stajališta Ustavnog suda Republike Hrvatske o ustavnim i konvencijskim jamstvima zaštite prava na dom u smislu članka 34. Ustava, u: Barbić, J. (ur.), Pravo na dom, Hrvatska akademija znanosti i umjetnosti, Zagreb, 2016., str. 53.-81.

14. Mihelčić, G., Novosti u ovrsi na nekretnini, Pravo i porezi, br. 10, 2014., str. 8.-14.

15. Mihelčić, G.; Marochini, M., Reforma ovrhe na nekretnini u hrvatskom pravu u svjetlu konvencijskog prava, Zbornik radova Aktualnosti građanskog i trgovačkog zakonodavstva i pravne prakse, br. 12, Mostar, 2014., str. 200.-213.

16. Mihelčić, G., u suradnji s Kontrec, D., Komentar Ovršnog zakona s opsežnom sudskom praksom i abecednim kazalom pojmova, Organizator, Zagreb, 2015.

17. Pražetina, R., Određivanje vrijednosti nekretnine u ovrsi, Pravo i porezi, br. 5, 2007., str. 8.-13.

18. Stokić, M., Vrijednosna ograničenja za ovršnu prodaju nekretnina kao sredstvo zaštite ovršenika, Aktualnosti hrvatskog zakonodavstva i pravne prakse: građansko, trgovačko, radno i procesno pravo u praksi, Godišnjak 22, 2015., str. 765.-772.

\section{POPIS PROPISA}

1. Konvencije za zaštitu ljudskih prava i temeljnih sloboda, Narodne novine Republike Hrvatske, Međunarodni ugovori, broj 18/1997, 6/1999, 8/1999, 14/2002, 13/2003, 9/2005, 1/2006, 2/2010.

2. Ovršni zakon iz 1996. godine, Narodne novine Republike Hrvatske, broj 57/1996, s kasnijim izmjenama i dopunama: Narodne novine Republike Hrvatske, broj 29/1999, 42/2000 - v. Odluku i Rješenje Ustavnog suda Republike Hrvatske, broj: U-I-510/1996, U-I-717/1996, U-I-1025/1999 od 5. 4. 2000., 173/2003, 194/2003 - v. Ispravak Zakona o izmjenama i dopunama Ovršnog zakona iz 2003., 151/2004, 88/2005, 121/2005 - v. Zakon o Upisniku sudskih i javnobilježničkih osiguranja tražbina vjerovnika na pokretnim stvarima i pravima, 67/2008, 139/2010 - v. čl. 339. Ovršnog zakona iz 2010.

3. Ovršni zakon iz 2010. godine, Narodne novine Republike Hrvatske, broj 139/2010, s kasnijim izmjenama i dopunama: Narodne novine Republike Hrvatske, broj 125/2011, 150/2011, 154/2011, 12/2012, 70/2012, 80/2012 - v. Odluku Ustavnog suda Republike Hrvatske, broj: U-I-1988/2011 i dr. od 19. 6. 2012.

4. Ovršni zakon iz 2012. godine, Narodne novine Republike Hrvatske, broj 112/2012, s kasnijim izmjenama i dopunama: Narodne novine Republike Hrvatske, broj 25/2013 - v. čl. 101. Zakona o izmjenama i dopunama Zakona o parničnom postupku iz 2013., 93/2014, 55/2016 - v. Odluku Ustavnog suda Republike Hrvatske, broj: U-I-2881/2014 i dr. od 1. 6. 2016., 73/2017.

5. Pravilnik o odobravanju pomoći za uzdržavanje u obliku zajma, mjerila i obilježja stana potrebnog 
za zadovoljavanje osnovnih stambenih potreba samca ili obitelji i o odobravanju pomoći iz socijalne skrbi iz 1998. godine, Narodne novine Republike Hrvatske, broj 28/1998, 117/2000, 81/2004.

6. Zakon o izmjenama i dopunama Ovršnog zakona iz 1999. godine, Narodne novine Republike Hrvatske, broj 29/1999.

7. Zakon o izmjenama i dopunama Ovršnog zakona iz 2003. godine, Narodne novine Republike Hrvatske, broj 173/2003.

8. Zakon o izmjenama i dopunama Ovršnog zakona iz 2005. godine, Narodne novine Republike Hrvatske, broj 88/2005.

9. Zakon o izmjenama i dopunama Ovršnog zakona iz 2011. godine, Narodne novine Republike Hrvatske, broj 125/2011.

10. Zakon o izmjenama i dopunama Ovršnog zakona iz 2014. godine, Narodne novine Republike Hrvatske, broj 93/2014.

11. Zakon o izmjenama i dopunama Ovršnog zakona iz 2017. godine, Narodne novine Republike Hrvatske, broj 73/2017.

12. Zakon o izmjenama Ovršnog zakona iz 2011. godine, Narodne novine Republike Hrvatske, broj $150 / 2011$.

13. Zakon o izmjenama Ovršnog zakona iz 2012. godine, Narodne novine Republike Hrvatske, broj $70 / 2012$.

14. Zakon o izvršnom postupku iz 1978. godine, Službeni list Socijalističke Federativne Republike Jugoslavije, broj 20/1978.

15. Zakon o javnim ovršiteljima iz 2010. godine, Narodne novine Republike Hrvatske, broj 139/2010, s kasnijim izmjenama i dopunama: Narodne novine Republike Hrvatske, broj 150/2011, 70/2012, $112 / 2012$.

16. Zakon o javnom bilježništvu iz 1993. godine, Narodne novine Republike Hrvatske, broj 78/1993, s kasnijim izmjenama i dopunama: Narodne novine Republike Hrvatske, broj 29/1994, 162/1998, 16/2007, 75/2009, 120/2016.

17. Zakon o parničnom postupku, Službeni list Socijalističke Federativne Republike Jugoslavije, broj 4/1977 - 35/1991; Narodne novine Republike Hrvatske, broj 26/1991, 53/1991, 91/1992, 112/1999, 88/2001 - v. čl. 50. Zakona o arbitraži, 117/2003, 88/2005 - v. čl. 129. Zakona o izmjenama i dopunama Ovršnog zakona, 2/2007 - v. Odluku USRH od 20. prosinca 2006., 84/2008, 96/2008 - v. Odluku USRH od 9. srpnja 2008., 123/2008 - ispravak, 57/2011, 148/2011 - pročišćeni tekst, 25/2013, 89/2014 - v. Odluku USRH od 11. srpnja 2014.

18. Zakon o socijalnoj skrbi iz 1997. godine, Narodne novine Republike Hrvatske, broj 73/1997, s kasnijim izmjenama i dopunama: Narodne novine Republike Hrvatske, broj 27/2001, 59/2001, 82/2001, 103/2003, 44/2006, 79/2007.

19. Zakon o socijalnoj skrbi iz 2013. godine, Narodne novine Republike Hrvatske, broj 157/2013, s kasnijim izmjenama i dopunama: Narodne novine Republike Hrvatske, broj 152/2014, 99/2015, 52/2016, 16/2017.

20. Zakon o stečaju potrošača iz 2015. godine, Narodne novine Republike Hrvatske, broj 100/2015. 


\section{POPIS SUDSKIH ODLUKA}

1. Europski sud za ljudska prava: predmet Rousk protiv Švedske, presuda od 25. srpnja 2013. Dostupno na: URL=http://hudoc.echr.coe.int/eng\#\{“ecli”:[“2013:0725JUD002718304”], “itemid”:[“001-123422”]\}. Pristupljeno 19. srpnja 2017.

2. Europski sud za ljudska prava: predmet Vaskrsić protiv Slovenije, presuda od 25. travnja 2017. Dostupno na: URL=http://hudoc.echr.coe.int/eng\#\{"languageisocode": [“ENG"], "respondent":[“SVN"],"documentcollectionid2":[“JUDGMENTS”],"itemid”:[“001-173102”]\}. Pristupljeno: 13. srpnja 2017.

3. Europski sud za ljudska prava: predmet Vrzić protiv Hrvatske, presuda od 12. srpnja 2016. Dostupno na: URL=https://uredzastupnika.gov.hr/UserDocsImages//dokumenti/Presude\% 20i\%20odluke// Vrzi\%C4\%87\%20protiv\%20Hrvatske,\%20presuda.pdf. Pristupljeno 19. srpnja 2017.

4. Europski sud za ljudska prava: predmet Zehenter protiv Austrije, presuda od 16. srpnja 2009. Dostupno na: URL=http://hudoc.echr.coe.int/eng\#\{“appno":[“20082/02”], “itemid”:[“001-93594”]\}. Pristupljeno 19. srpnja 2017.

\section{MREŽNI IZVORI}

1. Amandmanina Konačni prijedlogZakona o izmjenamaidopunama Ovršnogzakona iz travnja 2017. godine. Dostupno na: URL=http://www.sabor.hr/konacni-prijedlog-zakona-o-izmjenama-i-dopunam0035. Pristupljeno 18. srpnja 2017.

2. Izvješće Odbora za pravosuđe Hrvatskog sabora od 18. listopada 2016. o Prijedlogu Zakona o izmjenama i dopunama Ovršnog zakona iz listopada 2016. godine. Dostupno na: URL=http://www.sabor.hr/izvjesce-odbora-za-pravosude-o-prijedlogu-zako0034. Pristupljeno: 13. srpnja 2017.

3. Konačni prijedlog Zakona o izmjenama i dopunama Ovršnog zakona iz 2005. godine, Zagreb, svibanj 2005. Dostupno na: URL=www.sabor.hr/fgs.axd?id=4617. Pristupljeno 14. srpnja 2017.

4. Konačni prijedlog Zakona o izmjenama i dopunama Ovršnog zakona iz 2014. godine, Zagreb, lipanj 2014. Dostupno na: URL=http://www.sabor.hr/konacni-prijedlog-zakona-o-izmjenama-i-dopunama-ov. Pristupljeno 13. srpnja 2017.

5. Konačni prijedlog Zakona o izmjenama i dopunama Ovršnog zakona iz travnja 2017. godine, Zagreb, travanj 2017. Dostupno na: URL=http://www.sabor.hr/konacni-prijedlog-zakona-o-izmjenama-i-dopunam0035. Pristupljeno: 13. srpnja 2017.

6. Mišljenje i amandmani Vlade uz Konačni prijedlog Zakona o izmjenama i dopunama Ovršnog zakona, Zagreb, srpanj 2017. Dostupno na: URL=http://www.sabor.hr/konacni-prijedlog-zakona-o-izmjenama-i-dopunam0035. Pristupljeno 19. srpnja 2017.

7. Nacrt prijedloga Zakona o izmjenama i dopunama Ovršnog zakona iz svibnja 2016. godine, Zagreb, svibanj 2016. Dostupno na: URL= https://esavjetovanja .gov.hr /ECon /Main Screen?entityId=3365. Pristupljeno: 13. srpnja 2017.

8. Prijedlog Zakona o izmjenama i dopunama Ovršnog zakona iz listopada 2016. godine, Zagreb, listopad 2016. Dostupno na: URL= www.sabor.hr/fgs.axd?id=46799. Pristupljeno: 13. srpnja 2017. 


\section{THE PROTECTION OF THE DEBTOR IN LIGHT OF THE NOVELTIES IN ENFORCEMENT ON IMMOVABLE PROPERTY}

\section{Summary}

The aim of the paper is to discuss and analyse the novelties introduced in the enforcement procedure on immovable property by the latest Amendments to the Enforcement Law, particularly in the context of the protection of the debtor and the immovable property in which he/ she resides, and the property necessary for satisfying his/her basic needs and those of the persons that he/she is legally obliged to support. In this context, the paper contains a summary of the historical genesis on regulation of the enforcement procedure on immovable property, particularly in relation to the protection of the debtor in the period from the adoption of the first Enforcement Law of 1996 until the Law of 2012. There follows the analysis and discussion on the Amendments to the Enforcement Law of 2014 in questions of the protection of the debtor and the immovable property in which he/she resides, and the property necessary for satisfying his/her basic needs and those of the persons he/she is legally obliged to support. The third part of the paper is an analysis of the recent decision of the European Court of Human Rights (hereinafter: the Court) in case Vaskrsić v. Slovenia, in which the Court - different from previous practice - decided on a violation of the right to peaceful enjoyment of the possessions, referred to in Article 1 of the Protocol No. 1 to the Convention for the Protection of Human Rights and Fundamental Freedoms, in the enforcement procedure. At the same time, the Court pointed out the need to apply the proportionality test in the enforcement procedure on immovable property as well. In continuation of the discussion of the case Vaskrsić v. Slovenia, the novelties introduced in the enforcement procedure on immovable property and the protection of the debtor by the latest Amendments to the Enforcement Law of 2017 have been analysed and discussed. The concluding part of the paper comprises a summary of the research results, the evaluation of the novelties introduced in the enforcement procedure on immovable property in relation to the protection of the debtor and the immovable property necessary for satisfying his/her basic needs, as well as the author's consideration of the new legal objective of enforcement procedure.

Keywords: $\quad$ Enforcement on immovable property, protection of the debtor, European Court of Human Rights, Act on Amendments to the Enforcement Law of 2017, procedure

\section{(c) (1) (8)}

This work is licensed under a Creative Commons

Attribution-NonCommercial 4.0 International License.

Slađana Aras Kramar, PhD, Assistant Professor, Department of Civil Procedural Law, Faculty of Law, University of Zagreb. Trg Republike Hrvatske 14, 10000 Zagreb, Republic of Croatia. E-mail address: saras@pravo.hr. ORCID: http://orcid.org/0000-00028908-775X. 
